$$
\text { Universidade de São Paulo }
$$

Faculdade de Economia, Administração e Contabilidade Departamento de Administração

\title{
ADOÇÃO DE PROCESSOS VIRTUAIS ÀS ESTRATÉGIAS ORGANIZACIONAIS: ESTUDOS DE CASOS NO SETOR QUÍMICO
}

SIBYLLE SOPHIE HACKER

São Paulo 


\section{ADOÇÃO DE PROCESSOS VIRTUAIS ÀS ESTRATÉGIAS ORGANIZACIONAIS: ESTUDOS DE CASOS NO SETOR QUÍMICO}

SIBYLLE SOPHIE HACKER

Orientador: Prof. Dr. HIROO TAKAOKA

Dissertação apresentada à Faculdade de Economia, Administração e Contabilidade, da Universidade de São Paulo, para obtenção do título de Mestre em Administração.

São Paulo - SP

2003 
“O mestre que caminha à sombra do templo, rodeado de discípulos, não dá, de sua sabedoria, mas sim de sua fé e de sua ternura. Se ele for verdadeiramente sábio, não vos convidará a entrar na mansão de seu saber, mas vos conduzirá antes ao limiar de sua própria mente. O astrônomo poderá falar-vos de sua compreensão do espaço, mas não vos poderá dar a sua compreensão. Porque a visão de um homem não empresta suas asas a outro homem. E assim como cada um de vós se mantém isolado na consciência de Deus, assim cada um deve ter sua própria compreensão de Deus e sua própria interpretação das coisas da terra.”

Texto de Khalil Gibran em "O Profeta” 


\section{DEDICATÓRIA}

Ao meu marido Marcos, a quem tanto amo.

A minha pequena Sophie que nasceu durante o término deste projeto.

Aos meus pais, Felix e Nilza, por incentivarem sempre meus estudos.

Ao meu irmão Felix Conrad e minha cunhada Carla, pelas inúmeras contribuições.

A minha irmã Sylvia e meu cunhado Freddy, pelas dicas muito valiosas.

A amada Undine, que sempre esteve presente.

A Luciana Rovegno pela leitura do manuscrito.

A todos que diretamente ou indiretamente contribuíram para o término desta pesquisa. 
NOTAS GERAIS E AGRADECIMENTOS

Ao professor Hiroo Takaoka pela orientação.

Aos professores Ronaldo Zwiker e Antônio Vidal pelas correções.

Às empresas que colaboraram nas respostas e pela boa vontade e atenção dos respondentes. 


\section{SUMÁRIO}

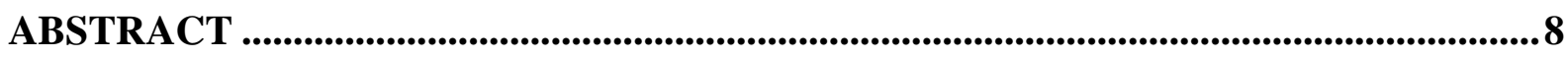

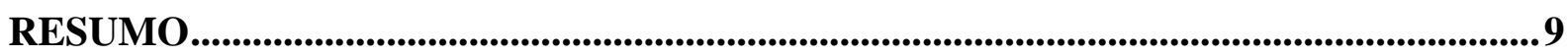

1. INTRODUÇÃO ..............................................................................................................10

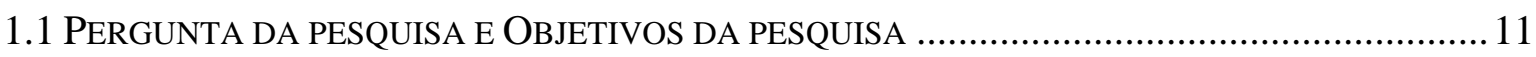

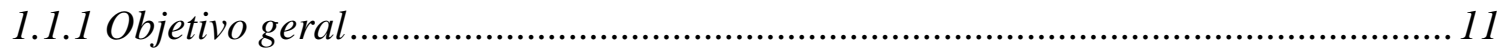

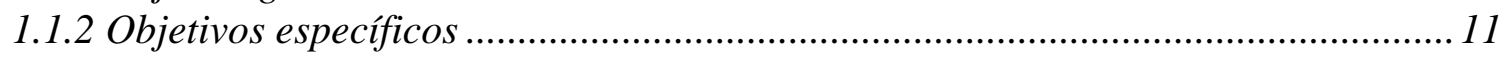

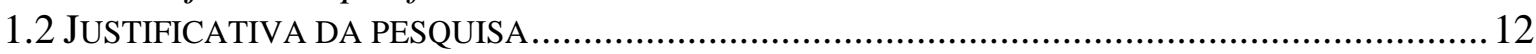

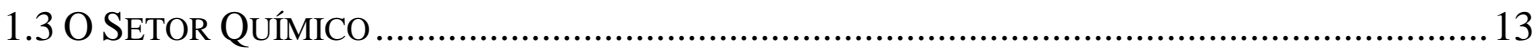

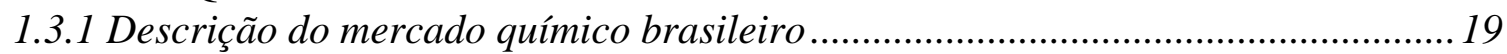

1.3.2 Uso do comércio eletrônico no setor químico ...........................................................22

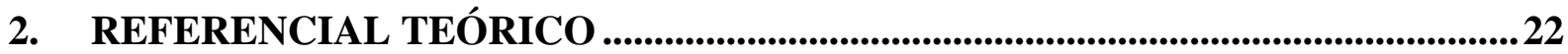

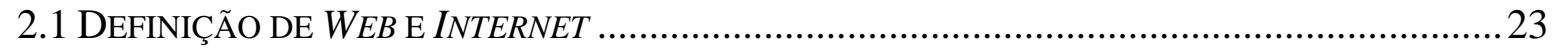

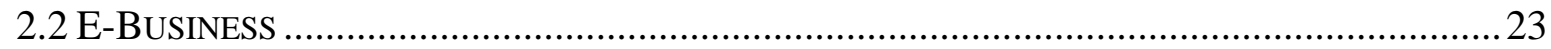

2.2.1 Barreiras e facilitadores na implantação do e-Business.........................................25

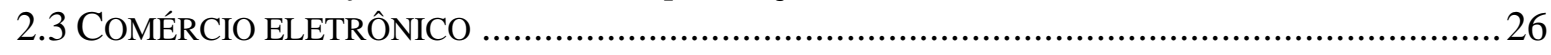

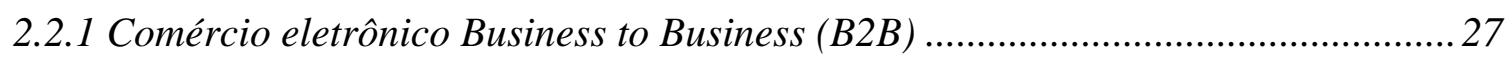

2.4 COMÉRCIO ELETRÔNICO VERSUS MARKETING ELETRÔNICO ….......................................... 30

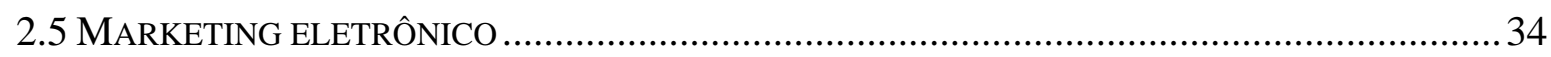

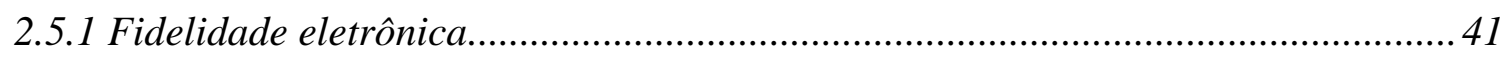

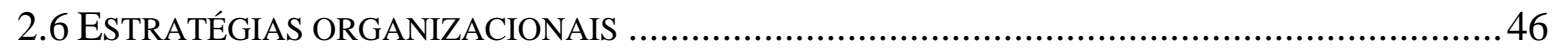

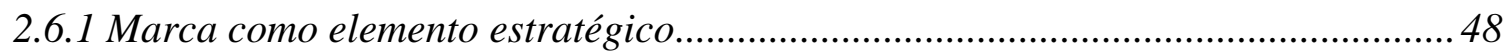

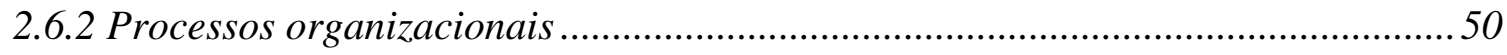

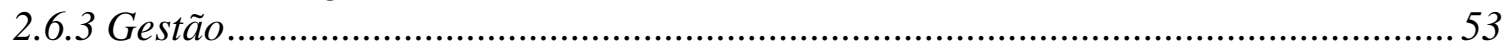

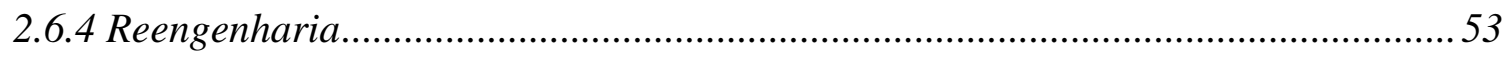

2.6.5 Modelo de avaliação de Gulati e Garino (2000) ......................................................56

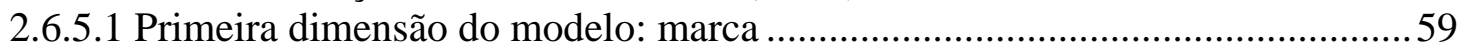

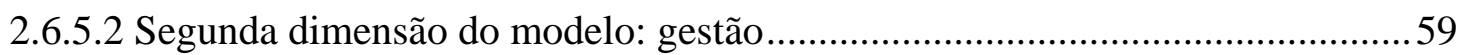

2.6.5.3 Terceira dimensão do modelo: operações .............................................................60 60

2.6.5.4 Quarta dimensão do modelo: composição do patrimônio líquido do acionista 60

2.6.6 Modelo de estrutura de Vasconcellos e Hemsley (1986) ......................................... 61

3. MATERIAIS E MÉTODOS.....................................................................................65

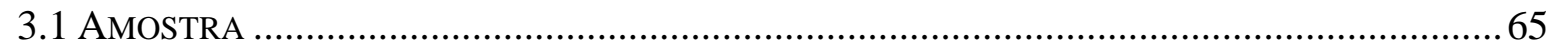

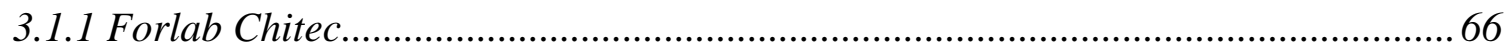

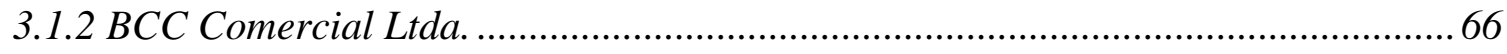

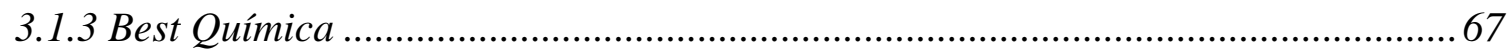

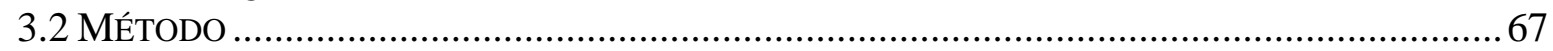

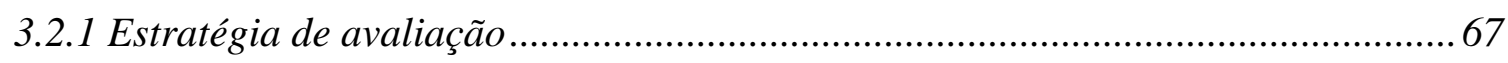

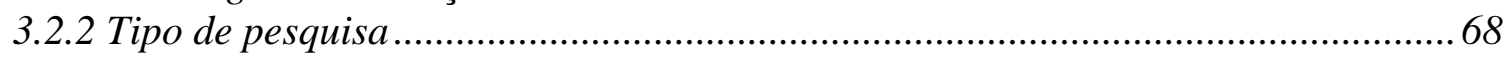

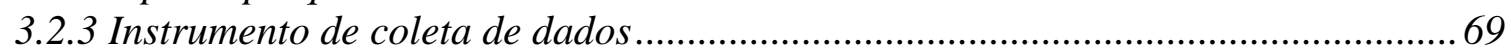

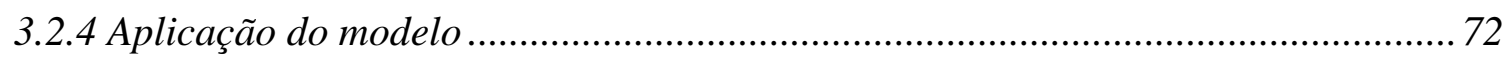

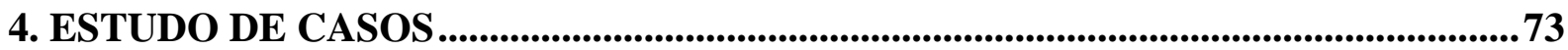




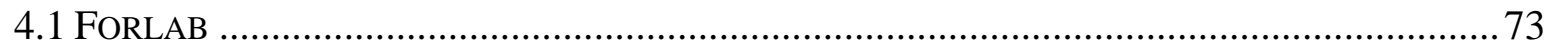

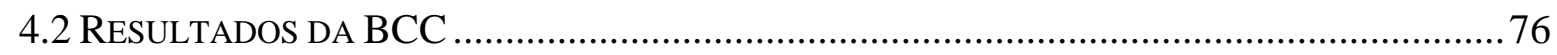

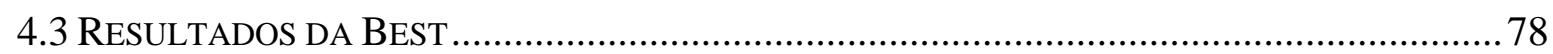

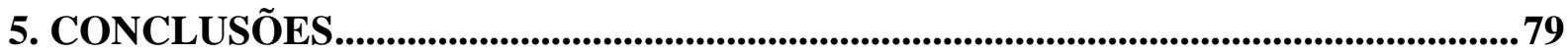

6. LIMITAÇÕES E RECOMENDAÇÕES ...................................................................8

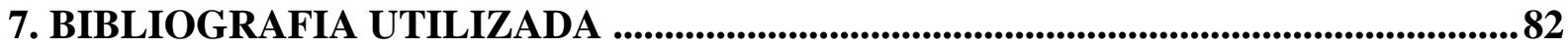

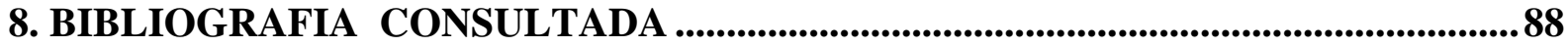

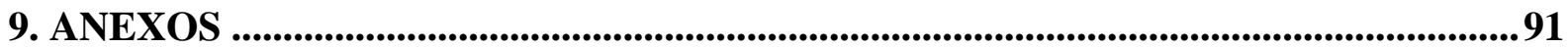

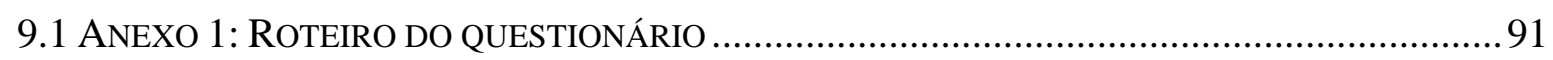

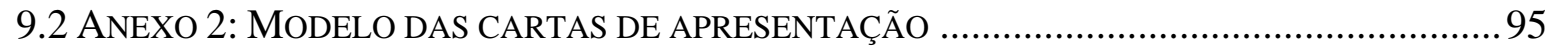

9.3 ANEXO 3: CARACTERÍSTICAS DAS ESCALAS BÁSICAS DE MEDIÇÃO...................................96

9.4 ANEXO 4: QUADRO SINOPSE DE IDENTIFICAÇÃO DOS ASPECTOS ORGANIZACIONAIS DA

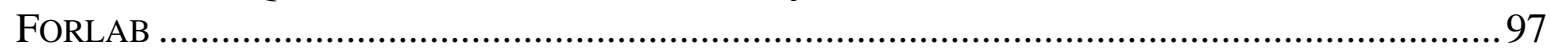

9.5 ANEXO 5: QUADRO SINOPSE DE IDENTIFICAÇÃO DOS ASPECTOS ORGANIZACIONAIS DA

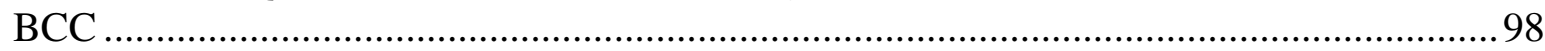

9.6 ANEXO 6: QUADRO SINOPSE DE IDENTIFICAÇÃO DOS ASPECTOS ORGANIZACIONAIS DA

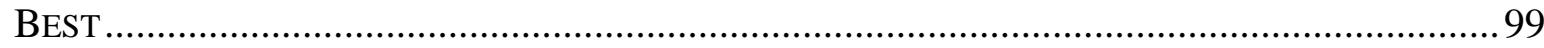


ABSTRACT 


\section{RESUMO}

Este trabalho tem como objetivo estudar como os processos virtuais estão sendo integrados às estratégias organizacionais de negócio das empresas químicas estão adotando o comércio eletrônico às estratégias organizacionais. O processo virtual engloba todo o processo de negócios, desde marketing, vendas, distribuição, serviço ao cliente e suporte pós-venda, bem como o gerenciamento de todos os ciclos de vida dos clientes e dos produtos.

Para isto utilizou-se o conceito de e-business, comércio eletrônico, reengenharia, aspectos organizacionais e marketing eletrônico como ferramentas de auxílio de análise e na busca de identificar uma tendência de adoção dos processos virtuais.

Através do levantamento bibliográfico foram identificados dois modelos relevantes para a avaliação dos aspectos organizacionais que foram utilizados para a formulação do modelo de pesquisa.

Finalizando, são apresentados os resultados de uma pesquisa exploratória com base em estudos de caso.

A pesquisa empírica contou com a participação de três empresas do setor químico com características diferentes e procurou através de estudo de casos avaliar como a adoção de processos virtuais está ocorrendo nestas empresas.

Resultados da pesquisa mostraram que não houve uma definição clara para o uso de processos virtuais e sua adoção não faz parte das estratégias organizacionais. Utilizam como uma extensão de estratégias de marketing já existentes. Não exploram as diferentes oportunidades de coleta de dados dos clientes que poderiam promover diversas formas de personalização de produtos e serviços, garantindo maior fidelização e diferenciação no mercado. 


\section{INTRODUÇÃO}

O tema comércio eletrônico e suas vantagens, desvantagens e características já foram bastante discutidos e explorados pela literatura e por trabalhos acadêmicos. Apesar disso, a correta adoção dos processos virtuais pela estratégia organizacional industrial ainda é um tema amplo a ser explorado, mas pouco discutido.

A adoção da Internet e dos processos virtuais altera aspectos organizacionais e modifica a noção de número de pessoas necessárias e de tempo bem como a abrangência das relações comerciais. O método tradicional de negócio, que utiliza várias pessoas em muitas posições ao longo do processo, pôde ser modificado com a utilização de computadores e de programas estruturados com economia de tempo (Trope, 1999).

Neste ponto, é importante definir claramente o modelo tradicional de negócios e os processos virtuais. O modelo tradicional de negócios é o empregado pelas empresas já estabelecidas no mundo "real”, no qual já possuem relacionamento com clientes, sistema de logística e processos organizacionais estruturados, ou seja, não nasceu na Internet. Processos virtuais consistem na utilização do comércio eletrônico para fazer negócio, envolvendo desde propaganda e marketing, vendas, pedidos, distribuição, serviço ao cliente, suporte pós-venda, reposição de estoque, gerenciamento de clientes e produtos (Seybold e Marshak, 2000).

A adoção e a integração de processos virtuais são definidas como a utilização de meios eletrônicos em conjunto com processos organizacionais já existentes (Trope, 1999). Nesse sentido, será utilizada a definição de adoção do comércio eletrônico como integração deste aos processos tradicionais de venda.

No novo modelo virtual surgiram os termos como nova e-conomia ou economia digital para definir o modo pelo qual os negócios existentes migram do lugar físico para o virtual (place to space), Weil e Vitale (2001). Segundo O’Neil (apud Bruner et al. 2001) os conceitos da nova e-conomia, principalmente do comércio eletrônico, seus processos e sua integração são muito dinâmicos e alteram-se rapidamente.

A flexibilidade e um correto posicionamento frente aos processos virtuais criam vantagem competitiva. Para Cronin (1996) e Kearney (2001), o primeiro passo para que a Internet se torne uma vantagem competitiva é conseguir um modelo adequado de integração da 
tecnologia com os objetivos organizacionais. Segundo esses autores, existem muitos modelos de integração do modelo virtual às funções do core business das organizações, o que representa atualmente um desafio para a efetiva implementação do e-business e do comércio eletrônico.

Um dos grandes desafios enfrentados pelas indústrias que desejam operar no comércio eletrônico é saber como devem adotá-lo. Realizar a integração total, parcial ou separação dos processos virtuais dos tradicionais é uma decisão estratégica, que depende de aspectos organizacionais e estruturais.

Este estudo pretende estudar a adoção do comércio eletrônico à estrutura organizacional e avaliar a integração dos processos virtuais ao modelo tradicional de negócio no setor químico.

\subsection{Pergunta da pesquisa e Objetivos da pesquisa}

\section{Pergunta da pesquisa}

Como ocorre a adoção de processos virtuais pelo modelo tradicional de negócio na insdústria química?

\subsubsection{Objetivo geral}

O objetivo principal deste estudo é:

- Avaliar como os processos virtuais são adotados pelos processos tradicionais de negócio.

\subsubsection{Objetivos específicos}

Além do objetivo principal, este estudo apresenta alguns objetivos específicos, os quais relacionam-se abaixo:

a) Avaliar a organização quanto a seus aspectos organizacionais

b) Identificar como as variáveis marca, gestão e operação, colaboram para a adoção do comércio eletrônico

c) Ampliar o conhecimento sobre as estratégias de adoção de processos. 


\subsection{Justificativa da pesquisa}

Constatou-se que o tema proposto é pouco explorado no setor químico, existindo pouca literatura na área de Administração de Informática e Gestão Organizacional.

O estudo de caso será no setor químico que é um mercado bastante representativo e um amplo campo a ser estudado.

Será uma contribuição para o desenvolvimento sobre os reflexos da implantação de processos virtuais nas empresas e poderá ser utilizado, posteriormente, como orientação no planejamento e elaboração de estratégias eficientes para o comércio eletrônico.

O quadro abaixo sintetiza, de modo claro e conciso, os objetivos desta pesquisa

\section{Quadro 1 - Objetivos}

\begin{tabular}{|c|c|c|c|}
\hline Objetivo geral & Objetivos específicos & Fundamentação teórica & $\begin{array}{c}\text { Técnica de } \\
\text { coleta }\end{array}$ \\
\hline $\begin{array}{l}\text { Avaliar como os } \\
\text { processos virtuais } \\
\text { são adotados pelos } \\
\text { processos } \\
\text { tradicionais de } \\
\text { negócio. }\end{array}$ & $\begin{array}{l}\text { Avaliar a organização quanto } \\
\text { a seus aspectos } \\
\text { organizacionais; } \\
\text { Identificar como as variáveis } \\
\text { marca, gestão e operação, } \\
\text { colaboram para a adoção do } \\
\text { comércio eletrônico. } \\
\text { Ampliar o conhecimento } \\
\text { sobre as estratégias de adoção } \\
\text { de processos. }\end{array}$ & $\begin{array}{l}\text { 1) Caracterização da era } \\
\text { virtual: comércio } \\
\text { eletrônico, e-business, } \\
\text { Internet, marketing } \\
\text { eletrônico e fidelidade } \\
\text { eletrônica. } \\
\text { 2) Caracterização do setor } \\
\text { químico } \\
\text { 3) Estratégias } \\
\text { organizacionais: revisão } \\
\text { dos conceitos de processos } \\
\text { organizacionais, gestão, } \\
\text { reeengenharia, marcas, } \\
\text { 4) Apresentação dos } \\
\text { modelos a serem estudados }\end{array}$ & $\begin{array}{l}\text { - Entrevistas com } \\
\text { gerentes das áreas } \\
\text { de vendas } \\
\text { - Questionário por } \\
\text { meio eletrônico e } \\
\text { pessoal }\end{array}$ \\
\hline
\end{tabular}




\subsection{O Setor Químico}

O setor químico possui grande diversidade de processos, produtos e aplicações, justificandose assim uma apresentação de suas características gerais e sua representatividade econômica.

Foram utilizados inicialmente dados fornecidos pela Associação Brasileira da Indústria Química (ABIQUIM). A ABIQUIM é uma entidade sediada na cidade de São Paulo, que congrega cerca de 160 empresas químicas de grande, médio e pequeno porte em todo Brasil.

De acordo com a Associação, o conceito das organizações no setor químico e sua abrangência têm sido objeto de divergência que dificulta a comparação e a análise dos dados. Esta dificuldade também foi citada por BRUNO (1995), onde registra uma dificuldade intrínseca do setor de estabelecer fronteiras precisas do nível industrial, não havendo uma configuração única para representar a cadeia produtiva do setor químico, por conseqüência, existindo várias apresentações que podem ser aceitas.

A ABIQUIM classifica o setor como empresas de uso intensivo de capital, utilizando assim a classificação por categorias de faturamento padrão SEBRAE e número de funcionários padrão FIESP (Federação das Indústrias do Estado de São Paulo).

A partir de 1994, o Ministério do Trabalho e do Emprego (MTE) implementou o novo sistema de classificação de atividades (CAE). Este sistema ainda não está sendo completamente utilizado pelo IBGE e por outras instituições que geram estatísticas similares. Desse modo, para efeito de comparabilidade, optou-se por continuar utilizando a classificação antiga (CNAE), onde o porte das empresas industriais, definidas como a união de todos os estabelecimentos de uma mesma empresa que exerçam a mesma atividade econômica, na mesma unidade da federação, são classificadas como: pequena e média empresa aquelas com mais de 25 empregados e com menos de 500 empregados, e como grandes com 500 ou mais empregados (CNI 2003).

Para o SEBRAE (2003), o número de empregados é um dos critérios mais utilizados na classificação do porte das empresas.

Quadro: classificação das empresas de acordo com o número de funcionários 


\begin{tabular}{|l|l|}
\hline Porte & Empregados \\
\hline Micro empresa & Na empresa: até 19 empregados \\
\hline Empresa de pequeno porte & Na empresa: de 20 a 99 empregados \\
\hline Empresa de médio porte & Na empresa: de 100 a 499 empregados \\
\hline Empresa de grande porte & Na empresa: acima de 500 empregados \\
\hline
\end{tabular}

Fonte: SEBRAE (2003)

Uma outra proposição de classificação do setor químico é de HÉRAUD e PIVOT (1989 apud BRUNO, 1995), onde o modo de subdivisão da empresa baseia-se na química de base e especialidades.

- Especialidades: produtos com diferencial. As decisões de compra estão mais ligadas a percepção de qualidade e diferencial do produto

- Commodities: produtos padronizados e sem diferencial entre os fabricantes, ou seja, produtos cuja estrutura e conceito são praticamente similares entre si. Por exemplo: xileno. Os produtos commodities desenvolvem nos consumidores uma percepção mais uniforme dos produtos. E as decisões de compras passam a ser mais valorizadas pelos atributos ligados à qualidade, aos preços e aos locais e condições de compra. 
Figura - Setor Químico

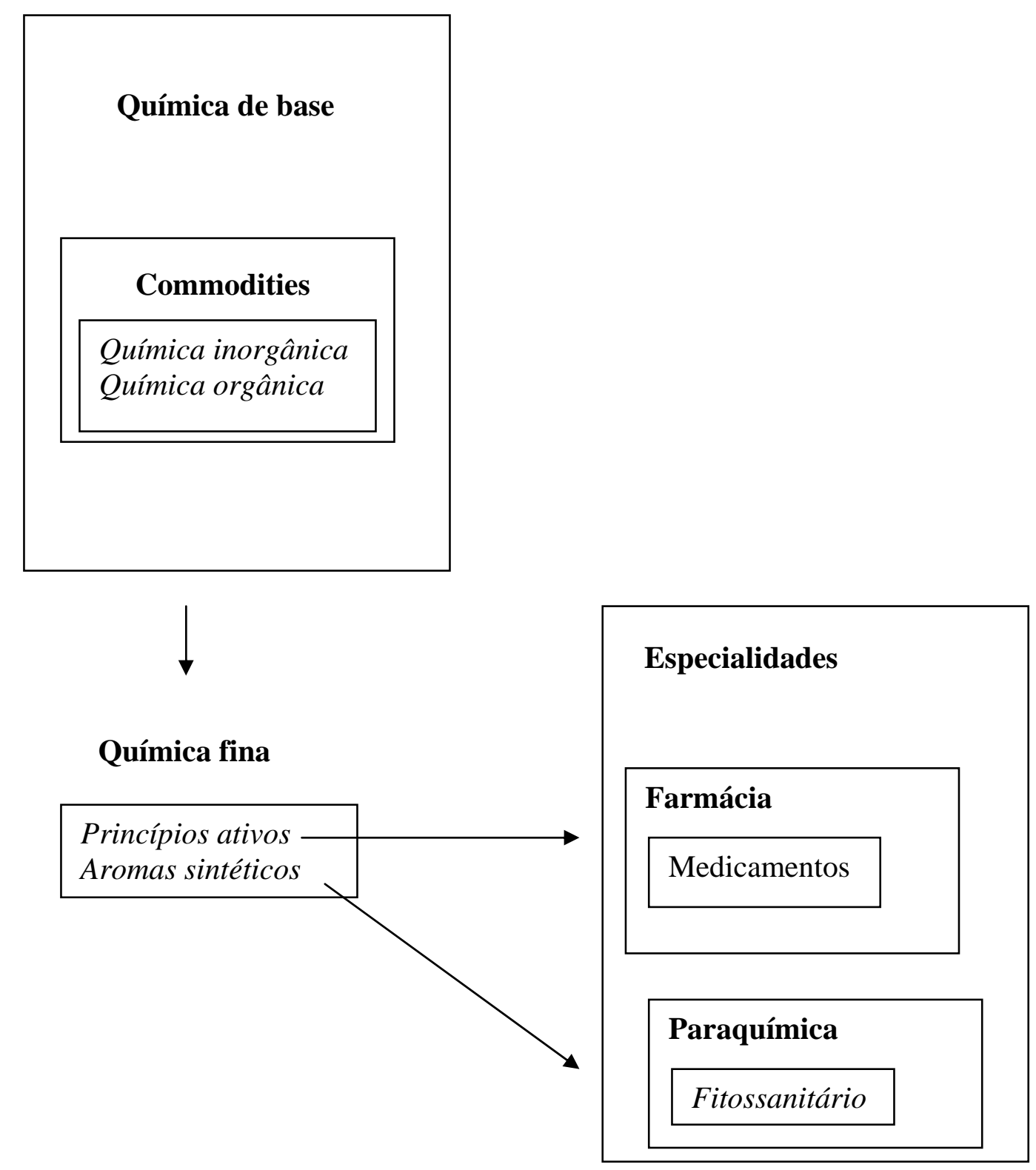

Fonte: HÉRAUD e PIVOT, 1989 (apud BRUNO, 1995). 
Na definição de HÉRAUD e PIVOT (apud BRUNO, 1995), indústria de base compreende dois segmentos: química pesada (orgânica e inorgânica) e química fina. Na química pesada, as escalas de produção são elevadas, contendo tanto produtos indiferenciados (commodities) como diferenciados (pseudocommodities), de baixo valor agregado. Na química fina as escalas de produção são baixas, com produtos indiferenciados de valor agregado mais alto. As especialidades (paraquímica e farmácia) referem-se a produtos diferenciados, fabricados em pequenas quantidades, de alto valor agregado e normalmente vendidos sob uma marca comercial.

Outra proposição é a de WEI, RUSSEL e SWARTZLANDER (1979), que classifica os produtos químicos segundo a escala de produção e as categorias de diferenciação de produtos (indiferenciado e diferenciado). Uma das características do setor químico é de ao mesmo tempo ser gerador de produtos finais e de produtos intermediários.

Tabela: comparação de produção anual de produtos indiferenciados e diferenciados

\begin{tabular}{|c|c|c|}
\hline Produção anual & Indiferenciado & Diferenciado \\
\hline $\begin{array}{l}\text { Alta } \\
\begin{array}{l}\text { - } 100 \text { milhares de } \mathrm{t} \text {; } \\
\mathrm{p}<0,4 \mathrm{US} \$ / \mathrm{kg} \\
\text { - } \text { milhares de } \mathrm{t} ; \\
0,4<\mathrm{p}<1,8 \mathrm{US} \$ / \mathrm{kg}\end{array}\end{array}$ & $\begin{array}{l}\text { Commodities } \\
\text { Ex.: ácido sulfúrico, } \\
\text { benzeno, eteno }\end{array}$ & $\begin{array}{l}\text { Pseudocommodities } \\
\text { Ex.: polietileno, } \\
\text { polipropileno }\end{array}$ \\
\hline $\begin{array}{l}\text { Baixa } \\
\text { - } 100 \mathrm{~kg} \text { - unidade de t; } \\
\text { p>1,8 US } \$ / \mathrm{kg}\end{array}$ & $\begin{array}{l}\text { Química fina } \\
\text { Ex.: aspirina, corantes }\end{array}$ & $\begin{array}{l}\text { Especialidades } \\
\text { Ex.: medicamentos }\end{array}$ \\
\hline
\end{tabular}

Fonte: Adaptado de WEI, RUSSEL e SWARTZLANDER, 1979.

Preço indicativo (p) no mercado dos EUA em 1976. 
Produtos indiferenciados são produtos químicos com composição química e propriedades físicas definidas, independentemente do fabricante. Podemos relacioná-los aos produtos tipo commodities.

Produtos diferenciados são produtos químicos com composição química e propriedades físicas variáveis, podendo cada fabricante lhe conferir característica para fins específicos. Podem ser classificados como especialidades.

Com o intuito de complementar esta classificação, segue quadro de sinopse.

Quadro: Classificação dos produtos químicos (em função da escala de produção, produtos obtidos e valor agregado).

\begin{tabular}{|c|c|c|c|}
\hline Setor & Química pesada & Química fina & Especialidades \\
\hline $\begin{array}{l}\text { Produção } \\
\text { anual }\end{array}$ & Elevada escala de produção & $\begin{array}{l}\text { Baixa escala de } \\
\text { produção }\end{array}$ & $\begin{array}{l}\text { Pequena } \\
\text { quantidade }\end{array}$ \\
\hline Produtos & $\begin{array}{l}\text { Produtos indiferenciados } \\
\text { (commodities) e diferenciados } \\
\text { (pseudocommodities) }\end{array}$ & $\begin{array}{l}\text { Produtos } \\
\text { indiferenciados }\end{array}$ & $\begin{array}{l}\text { Medicamentos e } \\
\text { fitossanitários }\end{array}$ \\
\hline Valor & Baixo valor agregado & $\begin{array}{l}\text { Maior valor } \\
\text { agregado }\end{array}$ & $\begin{array}{l}\text { Alto valor } \\
\text { agregado. } \\
\text { Geralmente } \\
\text { vendidos sob uma } \\
\text { marca comercial }\end{array}$ \\
\hline Exemplo & $\begin{array}{l}\text { Commodities: ácido sulfúrico, } \\
\text { xileno } \\
\text { Pseudocommodities: polietileno }\end{array}$ & $\begin{array}{l}\text { Vitamina C } \\
\text { Corantes } \\
\text { alimentares }\end{array}$ & $\begin{array}{l}\text { Aspirina }{ }^{\circledR} \\
\text { Buscopan } \AA\end{array}$ \\
\hline
\end{tabular}


MONATERI (1990) e FRADET (1986 apud BRUNO 1995) caracterizam o setor por tipo de produto: commodities e especialidades.

Quadro comparativo das características por tipo de produto

\begin{tabular}{|l|l|l|}
\hline Característica & Commodities & Especialidades \\
\hline Número de produtos & Pequeno & Grande \\
\hline Linhas de produto & Poucas & Muitas \\
\hline Escala de produção & Grande & Pequena \\
\hline industrial & Grande & Pequena e média \\
\hline Equipamentos & Complexos e específicos & Multiuso \\
\hline Fator de competitividade & $\begin{array}{l}\text { Competência industrial e } \\
\text { técnica comercial de } \\
\text { aplicação }\end{array}$ & $\begin{array}{l}\text { Conhecimento do } \\
\text { mercado; criação de } \\
\text { produtos de melhor } \\
\text { desempenho }\end{array}$ \\
\hline
\end{tabular}

Fonte: Adaptado de MONATERI, 1990 e FRADET, 1986 (apud BRUNO, 1995).

De acordo com a ABIQUIM, a ONU aprovou uma nova classificação internacional para a indústria química, incluindo-a na Revisão $\mathrm{n}^{\circ} 3$ da ISIC (International Standard Industry Classification). Utilizando-se deste critério, a ABIQUIM em conjunto com o Instituto Brasileiro de Geografia e Estatística - IBGE, enquadraram os produtos, considerando-se como do setor químico, os seguintes segmentos:

- Fabricação de produtos inorgânicos;

- Fabricação de produtos químicos orgânicos;

- Fabricação de resinas e elastômeros; 
- Fabricação de fibras, fios, cabos e filamentos contínuos artificiais e sintéticos;

- Fabricação de produtos farmacêuticos;

- Fabricação de defensivos agrícolas;

- Fabricação de sabões, detergentes, produtos de limpeza e artigos de perfumaria;

- Fabricação de tintas, esmaltes, lacas e produtos afins;

- Fabricação de preparados químicos diversos.

É pertinente trazer um esclarecimento quanto ao termo comumente utilizado no setor químico “produto intermediário”. Designa o produto de um subsetor que servirá de matéria prima a um outro. Pode ser gerador de produtos intermediários e também de produtos finais para o mercado.

\subsubsection{Descrição do mercado químico brasileiro}

A ABIQUIM (Associação Brasileira das Indústrias Químicas) acompanha permanentemente o desempenho do setor químico brasileiro. Anualmente, fornece dados que contribuem para orientar o processo decisório das associadas. Para a elaboração deste trabalho serão utilizadas as informações fornecidas pelo anuário da ABIQUIM em conjunto com levantamento de dados em cada organização da amostra.

De acordo com o anuário da Associação Brasileira das Indústrias Químicas (ABIQUIM, 2002), o faturamento líquido do setor químico brasileiro foi de US\$ 38,3 bilhões em 2001. Em moeda nacional, o faturamento cresceu 13\% e atingiu quase R 90 bilhões.

Este mercado representa um enorme espaço a ser explorado e uma gama ampla de oportunidades. Vide tabela abaixo com o demonstrativo do faturamento líquido do setor.

Tabela: Faturamento líquido do setor químico Mundial (1995-2001)

(Dados consolidados: em US\$ bilhões)

\begin{tabular}{|l|l|l|l|l|l|l|l|}
\hline Países/ano & 1995 & 1996 & 1997 & 1998 & 1999 & 2000 & 2001 \\
\hline
\end{tabular}




\begin{tabular}{|l|l|l|l|l|l|l|l|}
\hline $\begin{array}{l}\text { Total } \\
\text { estimandial }\end{array}$ & 1.601 & 1.599 & 1.607 & 1.572 & 1.624 & 1.712 & 1.719 \\
\hline EUA & 386 & 393 & 418 & 419 & 431 & 459 & 454 \\
\hline Japão & 251 & 219 & 203 & 177 & 201 & 222 & 213 \\
\hline Alemanha & 148 & 142 & 134 & 130 & 130 & 125 & 119 \\
\hline China & 61 & 68 & 75 & 81 & 89 & 99 & 109 \\
\hline França & 85 & 84 & 78 & 79 & 78 & 76 & 74 \\
\hline Itália & 65 & 66 & 63 & 62 & 61 & 60 & 60 \\
\hline Coréia & 39 & 43 & 47 & 45 & 49 & 52 & 53 \\
\hline Reino & 54 & 54 & 53 & 51 & 52 & 50 & 51 \\
\hline Unido & 41 & 43 & 46 & 44 & 36 & 44 & 38 \\
\hline Brasil & 25 & 27 & 29 & 30 & 31 & 34 & 37 \\
\hline Índia & & & & & & & \\
\hline
\end{tabular}

Fonte: Anuário ABIQUIM (2002)

Figura: Resumo do faturamento líquido do setor 


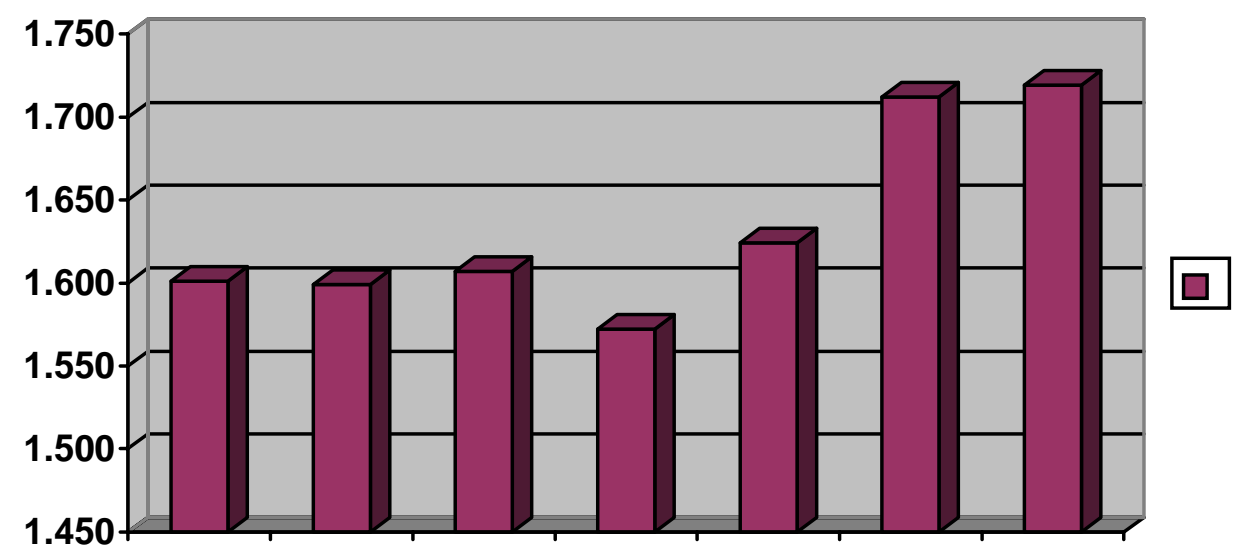

Fonte: adaptado do Anuário ABIQUIM (2002)

De acordo com o Anuário ABIQUIM (2001), a taxa de crescimento anual da fabricação de produtos químicos superou o crescimento do PIB e do setor industrial como um todo. Dados divulgados pelo CEFIC (Conselho Europeu das Confederações do setor químico) indicam que a produção química na Europa cresceu 3,2\% a.a., de 1990 a 2000, enquanto o PIB, no mesmo período, cresceu 2,0\% e o setor industrial 1,8\% a.a. Nos Estados Unidos, a taxa anual de crescimento da produção química foi de 2,7\% e no Japão, 1,8\% a.a. A indústria brasileira apresentou crescimento semelhante ao dos líderes mundiais.

Esta representatividade confere ao setor uma importância na base econômica. Como fornecedora de uma gama muito diversificada de produtos, muitos setores dependem dela direta ou indiretamente. Segundo dados divulgados pelo IBGE (2001), a fabricação de produtos químicos é responsável por 14\% do total da receita da indústria de transformação brasileira, ocupando a segunda posição atrás da fabricação de produtos alimentícios e de bebidas. O setor químico ocupa também participação importante no PIB, com praticamente $3 \%$.

Estes dados mostram a importância do estudo do setor químico e a procura de mecanismos que melhorem a eficácia e eficiência do setor. 


\subsubsection{Uso do comércio eletrônico no setor químico}

BRUNO (1995) alerta que a tecnologia é uma das fontes de obtenção de diferenciação competitiva no setor químico. VASNETSOV (2002), prediz um aumento constante na adoção de novas tecnologias, na área do comércio eletrônico, pelas empresas químicas nos próximos anos. Apesar disto, sua lucratividade, de acordo com o autor, estará ameaçada nos próximos três anos. O aumento da competição do setor e o maior acesso às informações colaboram para esta queda de lucratividade. Após este prazo culminará a criação de um mercado para futuros e ferramentas de gerenciamento de risco que ajudarão a reduzir a volatilidade de preços dos produtos químicos, aumento das margens de lucratividade e melhoria nas relações de precificação das companhias químicas. Espera-se também uma diminuição dos custos e aumento da velocidade das transações.

VASNETSOV (2002) acredita também que o e-business das empresas químicas reduzirá os preços de vendas. Esta redução da margem de lucro será mais acentuada no segmento de produtos especializados, pois há uma tendência de comoditização dos produtos e maior competição de preços. Para o autor, estas perdas serão maiores nos picos do ciclo econômico do setor químico, ou seja, "em épocas de maior competição". Entretanto em ciclos de menor competição, os preços se elevarão retornando a lucratividade.

Existe uma lacuna no que tange estudos de como está sendo adotado e implementado o comércio eletrônico no setor químico brasileiro. Embora a literatura aponte um crescimento nas atividades de comércio eletrônico no setor B2B, há poucos estudos sobre a caracterização de seus negócios eletrônicos.

\section{REFERENCIAL TEÓRICO}

Se o comércio eletrônico for diferente de e-business, deve explicitar as diferenças.Deve deixar claro o significado do comércio eletrônico neste trabalho.

Como seu trabalho só analisa B2B, é melhor eliminar a discussão de outras modalidades para não sair do foco que é B2B.

Apesar dos tópicos fidelização e marketing eletrônico serem interessantes, não sei se no trabalho vale a pena detalhar. Manter apenas se for relevante. 


\subsection{Definição de Web e Internet}

A Web (World Wide Web ou www) é um sistema que permite a troca de dados pela Internet de maneira eficiente e rápida (Ellsworth e Ellsworth,1997). Albertin (2000) considera a Web como uma coleção de documentos distribuídos localizados em computadores de todo o mundo. Gurus da era digital predizem um aumento contínuo na utilização desse canal na realização de trocas comerciais, que permite acesso 24 horas por dia, sete dias por semana (Aaker, Kumer e Day, 1998).

Para Mattar (2002), a Web caracteriza-se como um sistema de comunicação que transmite material de texto e de imagem diversos. Centenas de computadores interconectados, em que o elemento principal é a World Wide Web, a qual podem acessar e fazer uso dos os recursos da Internet. Para o autor, a Web é praticamente sinônimo de Internet, pois mesmo os sites que não possuem formato de hipermídia podem ser acessados por meio da Web.

Neste trabalho, será utilizada a definição de Mattar (2002), em que Web é sinônimo de Internet. A interatividade e a conectividade da Internet oferecem vantagens para as organizações, possibilitando mudanças nas relações comerciais e maior interação entre informação e cliente (Aaker, Kumar e Day, 1998). A interatividade é definida como a capacidade de novos sistemas de comunicação retornarem ao usuário por meio de uma tecnologia de informação. Assim, a Internet como ferramenta da informática, possibilita o armazenamento, a disponibilização, o compartilhamento de informações e o uso do comércio eletrônico.

Para o estudo da adoção de processos virtuais necessita-se rever os conceitos de comércio eletrônico e e-business.

\subsection{E-Business}

E-business, de acordo com Kalakota e Robinson (1999), é a forma de designar os processos de negócios, aplicativos empresariais e a estrutura organizacional necessários para criar modelos de negócios de alto desempenho. A empresa SAP (2003) define e-business como fazer negócios usando um meio eletrônico em substituição aos meios tradicionais. Incorpora tanto as formas de negócio entre empresas $(B 2 B)$, entre empresas e consumidores $(B 2 C)$ e 
entre consumidores $(C 2 C)$. Envolve catálogo eletrônico, meios de pagamentos seguros, processamento distribuído, satisfação dos clientes, data mining e outros. A implantação do $e$ business envolve networking, banco de dados distribuídos, segurança de informação. O sucesso de uma implantação requer não apenas o entendimento de seus custos e benefícios. Envolve a reengenharia dos negócios, a estruturação da cadeia de suprimentos e a gestão de mudanças incluindo a integração dos sistemas.

Para Turban (2000), o e-business possui uma definição mais ampla, não se apenas referindo à compra e venda, mas também incluindo serviços ao consumidor e colaboração entre parceiros de negócios bem como a condução de transações eletrônicas. O e-business utiliza a Internet como meio de comunicação, condutor de negócios e canal de distribuição.

De acordo com Drucker (2000), o impacto da revolução da informação está apenas começando no e-business, e a força motriz desse impacto é o comércio eletrônico. Para o autor, setores novos e inesperados surgirão. A concorrência não será mais local, mas sim desconhecerá fronteira. A Internet eliminará barreiras geográficas e possibilitará maior acesso às informações e à coleta de dados. Uma organização será capaz de expandir seus horizontes comerciais e de atuar em áreas diversas. Outro efeito destacado pelo autor com relação ao comércio eletrônico é que os novos canais de distribuição mudam os clientes, alteram a forma de comprar e o modo como os consumidores compram. Esse novo modelo de negócio altera as formas tradicionais de comunicação, de coordenação, de administração e de controle da gestão administrativa.

O e-business, para Kalakota (2001), é a digitalização dos processos de negócio e são mais relevantes que a tecnologia em si, alerta o autor. Assim, os gestores de empresas de sucesso têm de enfrentar o desafio de transformar todos os processos de negócio, que ainda existem no papel, em processos digitais.

O mundo empresarial é caracterizado por Kalakota (2001) pela complexidade e pela constante mudança. As empresas que querem alcançar sucesso têm de desenvolver uma estratégia que lhes permita rentabilizar ao máximo as novas tecnologias, além de implementar estratégias de e-business que lhes permitam servir e manter os clientes, gerir os fornecedores e integrar as redes de vendas de forma mais eficaz. Nesse cenário empresarial, os gestores têm de mudar as estratégias de gestão, de forma a obter a máxima vantagem do $e$-business. 
Kalakota (2001) apresenta, também, uma teoria inovadora sobre a passagem do modelo tradicional de negócios para o modelo de e-business. Para o autor, na última década, as empresas passaram por várias fases, cada uma delas orientada para uma forma de gestão: a reengenharia e os cortes orçamentais; a preocupação de fazer aumentar as receitas; a inovação e criação de valor. Paralelamente, surgiu uma fase de fusões e de aquisições. O panorama empresarial atual é caracterizado pelo autor como um desafio que as empresas enfrentam, pois devem absorver a inovação tecnológica e, ao mesmo tempo, fazer uma reengenharia da empresa, o que constitui um novo período de reengenharia e de corte de despesas. O autor enfatiza que as estratégias para conduzir o negócio com sucesso na era da informação consistem em administrar uma estratégia simultânea de inovação e de construção de relações próximas com os clientes. Alerta para o fato de que o problema tecnológico mais relevante para os gestores, na atualidade, é reescrever as aplicações de operações internas de negócio que utilizam a tecnologia da Internet. Os gestores envolvidos no e-business têm de enfrentar o problema da integração de processos, seja no interior das empresas, seja na cadeia de distribuição, seja com os clientes.

Neste trabalho, será utilizada a definição de Turban (2000) para e-business, ou seja, realização de negócios eletronicamente, não apenas se referindo a compra e venda, mas também incluindo serviços ao consumidor, colaboração entre parceiros de negócios e condução de transações eletrônicas. O e-business utiliza, nesse caso, a Internet e o comércio eletrônico como meio de comunicação, condutor de negócios e canal de distribuição.

\subsubsection{Barreiras e facilitadores na implantação do e-Business}

Para Slywotzky e Morrison (2000), Drucker (2000) e O’Connel (2000), os principais benefícios gerados pelo e-business são o alcance de novos consumidores, pois com tal serviço não existem barreiras geográficas, nem é necessária a criação de novos mercados, a melhora de resposta ao cliente e a expansão das possibilidades de fontes de receita e de lucratividade.

Como barreiras para uma implantação eficaz e bem-sucedida, Turban (2000), Kalakota e Robinson (2002), O’Connel (2002) citam os aspectos humanos, como equipe adequada, treinamento, aceitação de novos procedimentos, capacitação, escolha de tecnologia adequada, estrutura organizacional adaptada, operação de processos eficientes e integração de processos. 
Para Slywotzky e Morrison (2000) e Turban (2000), o comércio eletrônico é uma das ferramentas do e-business para o alcance de novos consumidores.

Entretanto, para Porter (2000), e-business não representa vantagem competitiva, pois a tecnologia é facilmente copiada por concorrentes e disponibiliza uma gama maior de possibilidades de comparação entre produtos. Com maior transparência de informações, haverá maior nivelamento dos preços. A rápida e imediata troca de informações eletrônicas possibilita a redução do tempo gasto no processo. Essa redução disponibiliza maior tempo para potencializar a qualidade de atendimento e para criar mecanismos úteis à personalização do atendimento ao cliente e personalizar o relacionamento.

\subsection{Comércio eletrônico}

Para Albertin (2000) e Reedy et al. (2000) o comércio eletrônico é um mecanismo de realização de negócios por meio do uso de tecnologias de informação. Esta nova ferramenta virtual possibilita o surgimento de novos processos de comercialização e novos meios de comunicação (McKenna, 1992).

Os negócios business to business (interempresariais) já estão crescendo na Internet (Kaplan e Sawhney, 2000). Alguns autores alertam para o fato de que a realidade de hoje não é necessariamente a mesma de amanhã. As transformações ocorrem com muita rapidez e são imprevisíveis (McKenna, 1992).

Para o mesmo autor, nesta nova era, a diversidade de produtos e de serviços aumentará até em pequenos segmentos de mercado. A competição mundial cresce, o mercado fica tão segmentado que os nichos tornam-se soberanos, as distinções entre os produtos ficam pouco nítidas, os ciclos de vida dos produtos são acelerados, os canais de distribuição estão em fluxo constante, o ambiente de negócios e o curso dos eventos competitivos são imprevisíveis, consumidores estão bem informados, com acesso crescente à informação sobre os produtos, e há maior conhecimento tecnológico pelos consumidores.

Para Laudon e Laudon (1996), a interdependência entre as organizações e os sistemas de informação é crescente. As estratégias organizacionais, as regras e os procedimentos 
relacionam-se intrinsecamente com software, hardware, dados, telecomunicações e outros. Esse relacionamento aumenta a complexidade dos sistemas.

Aldrich (2000) alerta para o fato de que as empresas, na era virtual, devem empregar processos que interajam dinamicamente com os clientes. Os ciclos de tempo são reduzidos, e as matérias-primas podem ser facilmente obtidas e localizadas. A informação colocará o cliente no centro das prioridades e estratégias.

Um dos grandes desafios no reposicionamento da organização para dar suporte aos processos eletrônicos relacionados ao cliente é, de acordo com Seybold e Marshak (2000), reunir as informações relevantes sobre cada cliente e fazer com que elas fluam automaticamente de um aplicativo para outro, ou seja, de lançamento de pedido para verificação de crédito, depois para contabilidade e controle de estoque. Os negócios estão sendo canalizados para a Internet assumindo características dinâmicas, rapidez e aspectos altamente competitivos (Amit e Zott, 2001).

\subsubsection{Comércio eletrônico Business to Business (B2B)}

O comércio eletrônico pela Internet está aumentando (Hammond, 2002). Muitos autores alertam para o fato de que o comércio entre empresas representa maior parte das transações. Neste trabalho, será utilizada a classificação de Turban (2000), segundo a qual o e-business é subdividido a partir da natureza de suas transações nos seguintes tipos:

- Business to Business (B2B): comércio realizado entre organizações;

- Business to Consumer (B2C): são transações de varejo com compradores individuais;

- Consumer to Consumer (C2C): consumidores vendem diretamente a consumidores;

- Consumer to Business (C2B): indivíduos que vendem produtos para organizações.

Nakamura (2001) alerta que, para obter um B2B eficaz, não bastam leilões e um website bem elaborado, sendo também necessário o uso de outras ferramentas do e-business para que estratégias de relacionamento com clientes, políticas eficazes de cadeia de suprimento e elementos de automatização de processos dentro da cadeia de comercialização sejam estratégias efetivadas com sucesso. Em Weil e Vitale (2001), os fatores mais importantes nas 
relações comerciais são os fluxos de produtos, dinheiro e informações entre os envolvidos, não havendo distinção entre $B 2 B$ e $B 2 C$.

Apesar das várias especulações sobre as vendas pela Internet, o mercado $B 2 B$ vem crescendo de forma mais consistente e representa a maior parte dos negócios efetuados por esse novo meio de comunicação (Lazzarini, Neves e Chaddad, 2000). Para os autores, os benefícios trazidos pelas transações $B 2 B$ pela Internet não são novidade, como a possibilidade de troca rápida de informações, a automação de gestão da cadeia de suprimentos, a possibilidade de otimização e a redução de estoque. Tudo isso já era preconizado por técnicas de gestão de cadeia de suprimento, tais como ECR (efficient consumer response) e EDI (eletronic data interchange), que focavam respectivamente a gestão integrada do fluxo de produtos ao longo da cadeia e a troca de informações, por computador, de processos gerenciais de compra e venda.

$O$ grande valor adicionado da Internet no mercado $B 2 B$ reside na externalidade de rede, que ocorre quando a adoção de uma tecnologia por um determinado agente econômico afeta positivamente a propensão de outros agentes em adotar essa mesma tecnologia, ou seja, quando mais as empresas aderirem a esse sistema, maior seus benefícios (Lazzarini, Neves e Chaddad, 2000). Primeiramente, as transações pela Internet baseiam-se em um sistema padronizado de troca de informações. Segundo, amplia-se o leque de possíveis compradores e supridores. A informação fica mais disponível, e a dependência em relação a determinados agentes com os quais a empresa transaciona diminui. Com o sistema padronizado da Internet, torna-se mais fácil para a empresa achar supridores alternativos.

O autor Saikovitch (2000) mostra, também, que 80\% dos negócios por meio de comércio eletrônico advêm do mercado B2B. No artigo da B2B Magazine (2003), as atividades do setor B2B cresceram mais que $100 \%$ no último ano. Calcula-se que $90 \%$ das empresas de capital genuinamente nacional farão mais de metade de suas transações comerciais pela Internet até 2005.

A pesquisa cita que as empresas estão realizando mais do que negócios na rede. São novos projetos, novas tecnologias e redefinição de estratégias. Alerta-se, também, para o fato de que o temor dos executivos de marketing de que os canais eletrônicos pudessem entrar em conflito com os tradicionais, os chamados "face a face", está se dissipando. 
A IDG (2003) também mostra que o comércio eletrônico no Brasil apresenta claros sinais de rápida evolução. Cita o artigo da $4^{a}$ edição da pesquisa Comércio Eletrônico no Mercado Brasileiro, realizada pela Fundação Getúlio Vargas (FGV) de São Paulo, onde de acordo com o estudo, o setor movimentou US\$2,1 bilhões em 2001 - US\$ 1,6 bilhão proveniente das transações entre empresas (B2B) e os US\$ 500 milhões restantes da venda para consumidores (B2C). O coordenador da análise, Alberto Luiz Albertini, lembra que esses valores representam 1,18\% das cifras movimentadas nas transações tradicionais entre empresas, e 0,35\%, se comparado ao comércio convencional entre empresas e consumidores.

Os aspectos mais relevantes para a realização do comércio eletrônico listados pelas empresas foram a necessidade de possuir e-mail, a troca eletrônica de dados e a existência de páginas na Internet. Também citaram a segurança e a privacidade, o relacionamento com clientes, o alinhamento estratégico e a adequação tecnológica.

De forma geral, as empresas ainda consideram as aplicações de comércio eletrônico como novos canais de promoção e vendas e não como uma forma efetiva de inovação de produtos e serviços. Com isso, ainda estão focando somente uma parte de seus processos de negócios os que são referentes ao relacionamento externo com o cliente e o fornecedor. O próximo passo evolutivo, de acordo com Albertini, será permear os processos internos e integrá-los com os externos de forma automática, pois atualmente o nível de integração ainda é baixo nas empresas brasileiras.

Silva (2002) analisou o que motivou a integração do comércio eletrônico nos negócios da empresa. Essa pesquisa foi elaborada junto à Fiesp (Federação das Indústrias do Estado de São Paulo), à Fipe (Fundação Instituto de Pesquisas Econômicas) e ao CNPq (Conselho Nacional de Desenvolvimento Científico e Tecnológico) e mostrou que apenas 5\% das indústrias realizam comércio eletrônico. De acordo com a pesquisa, a razão principal para a falta de negociação pela Internet é a dificuldade operacional, como processos de compras, estoques, produção, vendas, distribuição, cobrança e atendimento ao cliente, segundo a opinião de 58\% das empresas. Ou seja, dificuldades relacionadas à adequação dos processos internos para a implantação do comércio eletrônico. Um dos resultados negativos da pesquisa é a constatação de que faltam informações sobre comércio eletrônico aos empresários.

O mercado $B 2 B$ é mais representativo no comércio eletrônico. Muitos autores, em suas definições, não diferenciam o mercado $B 2 B$ do $B 2 C$ dificultando sua separação. Assim, a 
seguir, abordaremos marketing eletrônico e fidelidade eletrônica, realizando uma filtragem e buscando apenas definições que sirvam para o mercado intra-organizações.

\subsection{Comércio eletrônico versus Marketing eletrônico}

Segundo Albertin (2000), comércio eletrônico é a realização de toda a cadeia de valores dos processos de negócios, por meio da aplicação intensa das tecnologias de comunicação e de informação, atendendo aos objetivos dos negócios. A introdução do comércio eletrônico como novo canal de distribuição traz vantagens para a organização, pois os processos podem ser realizados de forma completa ou parcial tanto para consumidores, como para empresas ou intra-organizacionalmente.

Reedy et al (2000) definem comércio eletrônico como a realização de comunicação e de transações de negócios por meio de redes de computadores, mais especificamente a compra e venda de produtos e a prestação de serviços e transferência de fundos por meio de comunicações digitais. Para Turban (2000), comércio eletrônico é a entrega de informações, de produtos, de serviços ou de pagamentos por meio de linhas telefônicas, redes de computadores e outros meios eletrônicos.

O comércio eletrônico, com a utilização de catálogos na Web, possibilita aos clientes, fornecedores ou parceiros a obtenção de informações sobre os produtos da organização, constituindo um showroom 24 horas. Os custos e investimentos de distribuição e de produção de catálogos serão reduzidos, pois os interessados poderão imprimi-los instantaneamente para avaliar melhor o produto (Nakamura, 2000). Para Tigre (2002), os principais benefícios percebidos pelas empresas são: acesso a novos mercados, acesso à informação, melhor integração logística, maior visibilidade e novo canal de distribuição.

Tigre (2002) e Carvalho (2002) também alertam para as dificuldades da integração do comércio eletrônico na indústria. Dentre os fatores levantados citam dificuldades operacionais, falta de cultura em relação às ferramentas do comércio eletrônico, baixo índice de informatização das empresas, receio quanto ao sigilo das informações, falta de visão estratégica, falta de informação, medo referente à segurança e à privacidade, baixa capacitação dos envolvidos, baixa nível de integração dos sistemas internos, dificuldades tecnológicas e infra-estrutura inadequada. 
Para Boabaid (2003), muitas empresas que atuam no mercado virtual não possuem uma estratégia clara para a Internet. Utilizam-na como na extensão das ferramentas de marketing já existentes. É necessário que as organizações amadureçam e aprendam a integrá-la ao marketing mix, explorando seu potencial e desenvolvendo novas formas de criar valor para os clientes em termos de produtos e de serviços.

Carr (2003) alerta que a tecnologia de informação e, por extensão, o comércio eletrônico são, antes de tudo, um mecanismo de transporte que carrega a informação digital assim como a ferrovia carrega produtos. Como qualquer mecanismo de transporte, vale muito mais quando compartilhada do que quando usada isoladamente.

Com os recursos do marketing eletrônico, os hábitos de compra e as preferências dos clientes são detalhados por meio da criação de bancos de dados, para rastrear as atividades de compra. De acordo com Reedy et al (2000), o comportamento anterior ajuda a prever as ações futuras, auxiliando a organização em sua estratégia organizacional. Padrões de comportamento, como quantia gasta, preferências por itens ou marcas, data de compra, forma de pagamento e outros dados auxiliam na segmentação, nas decisões de marketing, no planejamento do comércio eletrônico e na definição de programas de fidelização.

Mediante programas de fidelização com dados coletados por comércio eletrônico, Data Warehouse e CRM, o histórico do cliente é armazenado, possibilitando maior personalização de acordo com o perfil de cada cliente. Rapidez, acessibilidade, precisão de informações geram vantagem competitiva. Essas ferramentas são meios eficientes para a melhoria das atividades de informática e de marketing.

É importante ressaltar que o comércio eletrônico não se limita a compras pela Internet e a transações da cadeia de suprimento entre grandes parceiros comerciais (Seybold e Marshak, 2000). Para os autores, o comércio eletrônico é fazer negócios eletronicamente, em todos os aspectos, desde o pedido, as vendas e o controle de estoque até o suporte pós-venda. A aplicação dessa tecnologia eletrônica na organização necessita de suporte por um banco de dados e de equipamentos sofisticados para atender à busca de dados.

Esse banco de dados avançado cria muitas oportunidades, seja por marketing direto, por cross marketing, por sorteios e por programas de fidelização, que servem como alicerce na construção de uma relação duradoura com o cliente por meio do marketing eletrônico. 
o Marketing direto: O banco de dados centralizado possibilita o rastreamento das informações de transação com o cliente. As ações de marketing direto ficam muito mais eficientes, e a empresa pode segmentar e focar suas mensagens com base nos hábitos de consumo do cliente, lançando campanhas e promoções em conformidade com esses hábitos.

o Cross Marketing: Linhas de produto complementares podem se beneficiar das oportunidades do cross marketing, alavancando um ao outro junto a seus clientes ou a seus bancos de dados gerados por programas de fidelização. Negócios que dispõe de programas de fidelidade em tempo real possuem a habilidade de pré-selecionar os tipos de clientes capazes de se interessar por produtos do parceiro e de ativar imediatamente uma mensagem no ponto-de-venda.

o Sorteios: As novas ferramentas possibilitam identificar segmentos no seu banco de dados, promover sorteios e enviar automaticamente por correio, telefone ou e-mail informações focadas nesse público alvo.

o Fidelidade ao fabricante: Programa de premiação, a fidelização em tempo real provê ao negócio a habilidade de identificar os tipos de clientes que respondem às ofertas, seus históricos e sua localização.

Esses bancos de dados, em conjunto com diferentes programas de marketing, trazem vantagens como: ampliação do mercado, melhora da comunicação, redução dos custos de venda e compras, diminuição dos custos administrativos, gerenciamento de estoque on-line e maior agilidade na administração da cadeia de suprimento.

De acordo com Goldman (2000) e Albertin (2000), o comércio eletrônico possibilita a redução das imperfeições de mercado. Os custos de transação são reduzidos, assim como os custos de venda e de produção na cadeia de fornecimento. Os sistemas do comércio eletrônico podem ser utilizados como estratégias de gerenciamento de clientes, possibilitando: conexão direta entre compradores e vendedores, eliminação dos limites de tempo e lugar, maior interatividade, podendo adaptar-se dinamicamente ao comportamento do cliente e possibilidade de atualização dos dados em tempo real.

Porter (2000) avalia que uma das maneiras de alcançar uma vantagem competitiva é por meio da diferenciação de atendimento e da qualidade. O marketing eletrônico possibilita a utilização de ferramentas úteis para alcançar eficiência em toda a cadeia do setor. 
Como desvantagens e problemas que surgem com esse novo meio de comércio, Porter (2000) e Reedy et al (2000) citam problemas com a precisão e confiabilidade dos dados, a pressão sobre as margens de lucro e a transformação dos produtos em commodities. A eliminação de barreiras de entrada, a ampliação do mercado e o maior acesso à informação tendem a gerar uma guerra de preços como meio de competição.

De acordo com os autores Ellsworth e Ellsworth (1997), os 4Ps de marketing (produto, preço, promoção e praça) também possuem papéis diferentes no comércio eletrônico, pois pode ser oferecido para o produto um maior número de mercadorias pela Internet. McKenna (1992) afirma que a diversidade de produtos e de serviço aumenta até em pequenos segmentos de mercado. As distinções entre produtos ficam pouco nítidas. Os ciclos de vida dos produtos são acelerados. Quanto ao fator preço, existe uma maior competitividade entre as empresas. No fator promoção, há a maior possibilidade de personalização e, no fator praça, a possibilidade de atingir todos os mercados sem barreiras geográficas, assim como a competição mundial aumenta e os mercados ficam tão segmentados que os nichos tornam-se soberanos.

A Internet também altera o comportamento de adoção de tecnologia. Uma avaliação possível sobre o comportamento da organização na adoção de inovações e de tecnologia foi descrita por Moore (1996), que afirma que existem os inovadores, entusiastas pela tecnologia com gosto pela aventura e que assumem riscos. Normalmente, são os primeiros clientes de novidades. Também existem os adeptos iniciais: são os visionários, líderes de opinião e agentes de mudanças. Suas expectativas são que, sendo os primeiros a explorar o novo recurso, poderão obter uma vantagem competitiva substancial e insuperável em relação à velha ordem. Os adeptos tipo maioria precoce são pragmáticos, acreditam em evolução e não em revolução, interessam-se em fazer os sistemas de suas empresas funcionarem eficazmente. Possuem opinião própria e procuram adotar inovações somente após um histórico comprovado de melhoria da produtividade, incluindo fortes referências de pessoas em quem confiam. Os adeptos tipo maioria tardia, mais conservadora, aguardam condições favoráveis; avessos a risco, mostram-se pessimistas quanto à capacidade de obter algum valor dos investimentos em tecnologia e só os realizam sob pressão. São muito sensíveis a preços, altamente céticos e muito exigentes. E, por fim, os retardatários: de estilo tradicional, são céticos, vivem do passado e recusam incertezas. São combatentes da alta tecnologia.

Na mesma linha de raciocínio, Kanter (2001) buscou classificar as empresas em "ritmistas” ou "retardatárias". Os ritmistas abraçam a Internet como uma oportunidade de questionar seus 
modelos existentes e de experimentar novas tecnologias para melhorar seus negócios. Eles têm predisposição para pensar nas conseqüências sistêmicas de suas proposições. Buscam equilibrar autonomia e integração, criando sinergia entre ofertas on-line e offline.

Houve dificuldade em encontrar uma definição única para o termo comércio eletrônico entre os autores. Nesse caso, foi escolhida a definição dos autores Turban (2000), Seybold e Marshak (2000), segundo a qual o comércio eletrônico engloba todo o processo de fazer negócios eletronicamente, em todos os aspectos, desde o pedido, as vendas, o controle de estoque até o suporte pós-venda. Logo, a melhora da comunicação por meio do comércio eletrônico colabora para os mecanismos de divulgação de produtos, a entrega de soluções, a resolução de problemas, a identificação de necessidades e a criação de fidelidade.

\subsection{Marketing eletrônico}

O marketing eletrônico é uma das ferramentas do comércio eletrônico que viabiliza a adoção deste e possibilita seu sucesso (Reedy et al, 2000).

Na literatura pesquisada sobre marketing eletrônico, não houve uma separação clara sobre que mercado (B2B ou B2C) estava abordando.

Atualmente, quase todas as transações comerciais deixam um registro eletrônico (Tapscott et al, 1998), possibilitando a criação de um rico banco de dados com informações como padrões de compras, freqüência e preferências. Para o autor, um novo negócio de data marketing está surgindo.

O marketing eletrônico engloba muitos conceitos do marketing tradicional. Uma das alterações mais facilmente detectada é a incorporação de linguagem e de semântica novas do mundo virtual. Termos como banco de dados, CRM, site, programas de fidelidade eletrônica e e-mail são, nesse meio, comumente utilizado.

Para Vavra (1993), o banco de dados de clientes ajuda a implementar o pós-marketing de diversas maneiras: 
- os esforços de marketing tornam-se tanto mais eficientes quanto eficazes, porque a empresa está hábil em identificar seus clientes mais importantes e, mais tarde, apresentar sua oferta, seu produto ou seu serviço adequado;

- a tecnologia possibilita a administração de extensa quantidade de dados, de maneira que a empresa interage com seus clientes de forma personalizada;

- um “diálogo" inteligente pode ser mantido com clientes ao descobrir interações contínuas, identificando mudanças no ato de compra e permitindo à empresa antecipar mudanças futuras;

- possibilidade de desenvolvimento de novos produtos a partir do conhecimento do perfil de cada cliente.

Verifica-se que o marketing pela Internet possibilita maior acesso à informação e às operações com uso integrado das informações. Brondmo (2001) compara o marketing tradicional direto e o marketing eletrônico (Tabela 2).

Tabela 2: Comparação entre marketing tradicional e marketing eletrônico

Marketing direto tradicional Marketing direto pela Internet

\begin{tabular}{|l|l|}
\hline \multicolumn{1}{|c|}{ Campanhas } & \multicolumn{1}{c|}{ Programas e relacionamentos } \\
\hline Listas & Bancos de dados integrados com informações de clientes \\
\hline Monólogos na difusão de informações & Diálogo e interatividade \\
\hline Grupos e segmentos & Indivíduos \\
\hline Contato intermitente & Contato contínuo \\
\hline Promocional & Informacional, educacional, de entretenimento e promocional \\
\hline Involuntário (opt-out) & Voluntário (opt-in) \\
\hline
\end{tabular}

Fonte: H. P. Brondmo, Fidelização: como conquistar e manter clientes na era da Internet, 2001, p. 45. 
É importante ressaltar o significado de termos como opt-in, que quer dizer que o cliente concorda explicitamente em receber seus e-mails, e opt-out, que é o oposto de opt-in, ou seja, opção de desengajamento do cliente em receber $e$-mails.

O crescimento e o desenvolvimento da lealdade dos clientes, estimulado por um banco de dados, podem ser bem representados pelo modelo de Considine e Raphael (apud Vavra 1993). Esse modelo descreve passos de intensificação do relacionamento do cliente com a empresa. São eles:

- clientes prováveis (suspects): universo de indivíduos ou organizações identificados como suspeitos de se tornarem clientes;

- clientes potenciais (prospects): indivíduos ou organizações que já ouviram falar dos produtos ou serviços de uma empresa e, portanto, têm algum grau de conhecimento dela, mas ainda não compraram.

- experimentadores: compradores de primeira vez, aqueles que estão testando produtos ou serviços de uma empresa; seu julgamento é velado;

- repetidores de compra: compradores que estão iniciando um compromisso mental com a empresa ao repetirem a compra do produto ou serviço;

- clientes fiéis: pessoas que compram uma variedade de produtos e serviços de uma empresa durante muito tempo, escolhendo as marcas desta entre outras concorrentes e, desse modo, demonstram lealdade;

- defensores (advogates): clientes que defendem ativamente uma empresa e a recomendam a seus amigos ou colegas de trabalho.

Brown (2001) lembra, também, que com todas essas novas tecnologias, a manutenção de clientes é a melhor maneira de alcançar um crescimento estável e lucrativo. É mais barato manter os clientes e desenvolver novos negócios com ele do que buscar novos clientes em uma porcentagem de um para três, em termos de despesas de marketing e vendas (Brown, 2001, p. XVI). Desse modo, manter o cliente é mais crítico do que atraí-lo (Kotler, 1994, p. 48).

Para Kotler (1994), a chave para manter o cliente é satisfazê-lo. Clientes satisfeitos:

- compram novamente; 
- falam favoravelmente com os outros sobre a empresa;

- prestam menos atenção às marcas e à propaganda do concorrente;

- compram outros produtos que a empresa colocar no mercado mais tarde.

Para Vavra (1993), o marketing de relacionamento engloba muitos conceitos como marketing personalizado, micro-marketing, marketing individualizado, marketing (one to one), marketing de retenção, marketing de freqüência, marketing de segmentação, marketing integrado, marketing interativo e marketing com banco de dados (Database Marketing). Para o autor, apesar das diferentes terminologias, a ênfase é a mesma - o reconhecimento da importância de tratar cada cliente individualmente e a procura de ferramentas na manutenção da fidelidade dos clientes. Nesse ponto, insere-se o marketing eletrônico, que busca a manutenção dos clientes de maneira interativa e virtual.

Segundo Reedy et al (2000), a base do plano de marketing é a pesquisa sobre as necessidades e os desejos do cliente em potencial, chamada análise da situação. O marketing eletrônico seria todas as atividades on-line ou eletrônicas que facilitam a produção e a comercialização de produtos ou serviços para satisfazer os desejos e as necessidades do consumidor. $\mathrm{O}$ marketing eletrônico aprimora o programa geral de marketing que, por sua vez, viabiliza os objetivos da empresa no comércio eletrônico.

Grönroos (1990) define a função de marketing como a interação de diversas áreas. Subdividea em duas funções: tradicional, como pesquisa, vendas, propaganda e promoções; e interativa, em que existe a interação entre comprador e vendedor. Este último conceito explora os meios de melhoria das relações e a ampliação dos negócios com o cliente. Para o autor, a função de marketing não se limita às atividades de vendas, mas estende-se a todas as áreas que agregam valor ao cliente e que possibilitam retê-lo. Propõe uma cultura de atendimento e de interação, na qual todos os níveis da organização são responsáveis pelo funcionamento dos processos para o cliente. O marketing eletrônico amplia esse conceito e possibilita a exploração desses meios.

Para Komenar (1997), marketing interativo é mais que uma ferramenta de multimídia usada para entreter ou engajar um cliente. Trata-se de um nível superior de marketing estratégico, possível por meio de tecnologia sofisticada e de um banco de dados inteligente capazes de dar respostas a relacionamentos interativos. 
A Internet, por ser em tempo real, impactou a propaganda tradicional. A tecnologia de hoje permite captação, medida e análise do input dos consumidores e, em seguida, de forma inteligente, classifica essa informação e aloca estrategicamente os recursos, tanto tradicionais quanto interativos. As empresas que procuram equilibrar risco e conhecimento bem como a compreensão desse novo mercado eletrônico estão em posição de obter grandes benefícios.

Para Reedy et al (2000), o marketing eletrônico deve ser visto como um gancho, no qual as atividades começam com a análise da situação. Em seguida, determina-se a estrutura do planejamento de marketing. O planejamento leva à implementação. Esse processo contínuo forma a base para o planejamento integrado. É o que se chama de comunicação de duas vias entre o cliente e o comércio eletrônico ou e-Marketing. Um forte programa de marketing eletrônico possibilita o sucesso do comércio eletrônico.

Albrecht (1998) lembra que os sistemas devem ser voltados para o atendimento das necessidades dos clientes e para a resolução de seus problemas.

De acordo com Reedy et al (2000), os recursos de marketing eletrônico introduzem precisão e velocidade, assim como ajudam a construir um relacionamento pessoal personalizado para cada cliente. Ao agregar valor ao produto ou ao serviço, a imagem e a marca são valorizadas.

Reedy et al (2000) afirmam que as comunicações, as atividades de transação e a pesquisa de informações fazem parte do marketing tradicional. O marketing eletrônico amplia esse conceito com o uso das ferramentas da comunicação eletrônica, como e-mail, discussão online em grupo, sites e a Web, que colaboram para a simplificação dos processos. É possível pesquisar produtos de maneira rápida, localizar novos fornecedores, novos clientes, identificar novos mercados e comparar produtos similares. Para o autor, os programas tradicionais de marketing são formas de comunicação unidirecionais para segmentos específicos ou para um grupo de consumidores. O marketing eletrônico desenvolvido para a Web permite maior possibilidade de personalização e o desenvolvimento de uma estratégia de maior afinidade entre o vendedor e o cliente.

Peppers e Rogers (1993) destacam o potencial do comércio eletrônico e da personalização. Para os autores, o velho paradigma de sistema de produção em massa, a mídia de massa e o marketing de massa estão sendo substituídos por um totalmente novo, o sistema econômico um-a-um (1:1). Esse sistema altera as regras da concorrência nos negócios e o crescimento. Em vez de mercado, a meta da maioria da concorrência será a fatia do cliente - um cliente por 
vez. O foco nos negócios será menos nos lucros de curto prazo derivados de volumes de transações trimestrais ou anuais e mais o tipo de lucro que pode ser realizado pela retenção de clientes de longo prazo e de valor vitalício.

Ellsworth e Ellsworth (1997) descrevem as possibilidades de utilização de algumas ferramentas de marketing e vendas, como:

- disponibilização de catálogos virtuais coloridos, com figuras e textos rapidamente atualizáveis;

- tela única de pedidos;

- serviço on-line de suporte ao cliente, com gráficos, fotografias, som e textos informativos;

- distribuição sem barreiras geográficas dos produtos;

- mala direta sem necessidade de impressão e custos de postagem;

- $\quad$ atendimento imediato ao cliente;

- recebimento on-line dos pedidos.

Para Varbusiness (apud McKenna, 1992), os clientes escolherão os produtos com base na força dos atributos não tecnológicos, quando a tecnologia oferecida for a mesma. Os modos de atendimento, de satisfação das necessidades dos clientes e de atendimento personalizados são alguns desses atributos não-tecnológicos que colaboram para a fidelidade a uma organização.

Uma empresa é capaz de diferenciar seus produtos com base em muitos fatores: tecnologia, preço, aplicação, qualidade, serviço, canais de distribuição, público alvo, clientes específicos e alianças (McKenna, 1992). Para o autor, oito conceitos são importantes para a implementação eficiente de um plano de relacionamento. São eles:

1) A organização precisa entender a dinâmica e as tendências do mercado, de modo a poder influenciar a forma por meio da qual o mercado posiciona seus produtos.

2) As organizações devem enfocar fatores de posicionamento intangíveis. Estabelecer posições baseadas em fatores subliminares é muito mais eficiente, tais como a liderança 
tecnológica, a assistência técnica, o suporte ou o enfoque maior em qualidade do que em preço e especificações técnicas.

3) A organização tem de desenvolver o produto total, atributos tangíveis e intangíveis.

4) Definir o mercado-alvo e atendê-lo muito melhor do que qualquer outra organização.

5) As organizações devem entender o sucesso e o fracasso para que possam desenvolver um processo coerente de desenvolvimento de novos produtos e marketing.

6) Entender as diferenças entre ser voltado para o mercado e ser voltado para marketing.

7) O valor de uma marca é diferente para produtos complexos e para bens de consumo de baixo risco.

8) A organização deve ficar atenta ao mercado e experimentar novos produtos.

De acordo com McKenna (1992), o novo marketing exige um ciclo contínuo, conectando a empresa ao cliente. É fundamental a definição de operação de uma empresa realmente orientada para o mercado: uma empresa adaptada às necessidades dos clientes, em constante mudança.

O marketing eletrônico possibilita criar parcerias com sistemas individualizados e personalizados. Individualizar permite ao cliente escolher o conteúdo on-line, oferecer individualmente opções de escolha. A personalização é voltada para grupos de clientes por interesse.

A pesquisa sobre clientes, a determinação de suas preferências e a avaliação da quantidade viável de personalização influenciará o grau de fidelidade eletrônica. Atributos que geram fidelidade são relevantes na escolha do canal a ser utilizado.

Pearson (1998) alerta para o fato de que a customização e, particularmente, a personalização é um dos fatores críticos para a criação e a sustentação da vantagem competitiva na Internet. As companhias que conseguem isso com seus sites na Web construirão “custos de mudanças” para os clientes e obterão a informação que precisam para diferenciar ainda mais suas ofertas. Para o autor, sem isso, muitas inovações na Internet são facilmente copiáveis pelos concorrentes. 
De acordo com Telma e Veloso (1999), muitas empresas apenas utilizam o marketing como meio de atrair novos clientes, desconsiderando o grau de importância de seus clientes atuais, perdendo, assim, duas grandes oportunidades:

a) aumentar a rentabilidade por cliente mediante um incremento no valor da compra média ou mesmo no número de compras por cliente.

b) aprender os hábitos/perfis de compra dos diversos clientes da base, identificando os melhores e separando-os em grupos homogêneos com características específicas, aumentando o retorno por meio de ações direcionadas.

Para os mesmos autores, os programas de fidelização são influenciados pelo intervalo de compra ou utilização: bens duráveis utilizam modelos de pós-venda e relacionamentos que não sejam baseados exclusivamente na compra, uma vez que as aquisições são feitas de maneira extremamente espaçada. Para os bens de consumo não-duráveis e serviços que possuem períodos de aquisição relativamente menores, é possível montar programas de fidelização com base na compra ou no uso, de maneira a estimular a diminuição desse intervalo.

Para McKenna (1992), a tecnologia permite que a informação flua bilateralmente entre o cliente e a empresa. Cria um ciclo de feedback que integra o cliente à empresa, permite que a empresa detenha o mercado, estabelece um diálogo, permite personalização e transforma o produto em serviço e o serviço em produto.

Todas essas definições e considerações mostram a importância do comércio eletrônico para as indústrias e como as ferramentas de marketing colaboram para uma maior lucratividade e competitividade no mercado $B 2 B$.

\subsubsection{Fidelidade eletrônica}

A fidelidade eletrônica é um dos aspectos do comércio eletrônico que aumenta a lucratividade das organizações. Algumas provocações ligadas ao tema do comércio eletrônico e sobre a fidelidade são relacionadas à importância do relacionamento acima da transação. McKenna (2000) lembra que a revolução da informação contribuiu para a melhoria da produtividade e 
para a diminuição da fidelidade do cliente. Organizações que tentarem viver mediante transações eletrônicas irão morrer (Keen apud Dickson e DeSanctis, 2001). Clientes significam mais que transações (Davenport et al). O mesmo autor alerta para a importância da manutenção de clientes, para a construção de relacionamentos e para o desenvolvimento de técnicas de fidelização de clientes.

Oliver (apud Brown 2001) define fidelidade como um “compromisso forte em recomprar ou repatrocinar um produto ou serviço preferido consistentemente no futuro, apesar das influências circunstanciais e tentativas de marketing que podem acarretar um comportamento de troca”.

Brown (2001) lembra que a retenção de clientes é um fator diferencial. As empresas capazes de oferecer alto nível de serviço de atendimento ao cliente fortalecerão suas marcas e defenderão suas posições no mercado.

A fidelidade é uma tentativa da organização de criar benefícios para o cliente e para retê-los a longo prazo. O processo de fidelidade é posterior ao processo de adoção (Kotler, 1993). A adoção é a última etapa, posterior aos estágios de conscientização, interesse e experimentação.

A fidelidade eletrônica pode ser definida como "comportamentos positivos tais como visitas e compras repetitivas, recomendações ou participação ativa em programa para clientes; não se relaciona apenas à satisfação" (Smith, 2001).

Brown (2001) cita algumas conquistas que empurram a organização em direção à abordagem de valor em longo prazo, como: (1) custo maior de conquistar um cliente novo do que manter um cliente antigo; (2) a Internet fornece uma visão clara de quem são os clientes regulares. Para Waitt (apud Brown 2001), a Internet pode ser utilizada como uma ferramenta para aprofundar as ligações com compradores.

Para Vavra (1993) a fidelidade de marca entre consumidores virtualmente desaparece, à medida que percebem que todas as marcas são praticamente iguais.

Os clientes mais lucrativos são, de acordo com a literatura, os mais exigentes. Reichheld (1996), Seybold e Marshak (2000) lembram que a retenção não pode ser considerada apenas uma estatística operacional, mas uma peça central que integra todas as dimensões da empresa e que mede seu desempenho na criação de valor para os clientes. A criação de valor para o cliente gera fidelidade e, por conseqüência, lucro e crescimento. 
De acordo com Stalk e Hout (1990), ser responsivo às necessidades dos clientes traz recompensas de quatro maneiras:

1. Os clientes são mais fiéis aos fornecedores consistentemente responsivos às suas necessidades.

2. A um fornecedor responsivo, os clientes se disporão a pagar um acréscimo sobre o preço habitual.

3. Os clientes irão comprar mais mercadorias e serviços de um fornecedor responsivo.

4. O fornecedor se vê estrategicamente avantajado quando consegue assegurar um cliente exigente.

Para Sviola e Shapiro (1995), à medida que os clientes tornam-se familiarizados com um determinado produto, passam a atribuir valor cada vez maior aos programas de prestação de serviço oferecidos pelo fabricante. Suas decisões de compra tornam-se cada vez mais sensíveis a programas de fidelidade.

O autor Reichheld (1996) mostra que os clientes fiéis são mais rentáveis. A cada ano, pode-se agregar maior valor e criar estratégias mais rentáveis para cada cliente. Segue, abaixo, gráfico 1 demonstrativo.

\section{Gráfico 1: Por que os clientes leais são mais rentáveis}

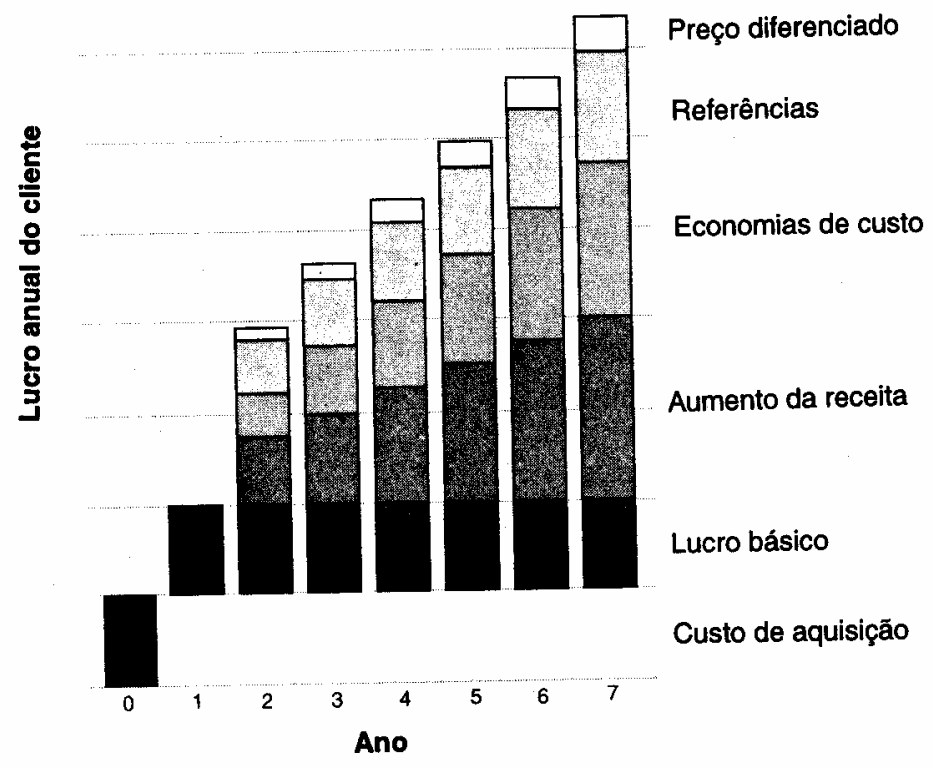


Fonte: F. F. Reichheld, A Estratégia da fidelidade, 1996, p. 42.

O custo de aquisição refere-se à quantia que a empresa deve investir para atrair novos clientes.

Lucro básico são as compras realizadas por clientes com os quais os fatores fidelidade, eficiência, tempo não alteram o lucro.

O aumento da receita por cliente explica-se pelo fato de que, com a retenção do cliente, os lucros com cada cliente tendem a crescer.

Na economia de custo os clientes já estão familiarizados com os produtos da empresa e tendem a ser menos dependentes da orientação da empresa quanto aos produtos, gerando produtividade e diminuição nos custos operacionais.

Referências são dadas por clientes satisfeitos, que recomendam a empresa às outras pessoas.

No estágio final, preços diferenciados, os clientes mais antigos são menos sensíveis ao preço da mercadoria que compram há muito tempo. Assim, na maioria dos setores, pagam preços maiores do que os novos clientes.

Pode-se concluir que a rentabilidade dos clientes e os padrões de lucro são diretamente correlacionados o grau de fidelização destes.

Novamente, Reichheld (1996) lembra que as empresa possuem clientes que desertarão em favor de um concorrente por um desconto de $2 \%$ e os que nem por um desconto de $20 \%$ desertariam. Essa força econômica que move diferentes clientes é o que se chama coeficiente de fidelidade. Esse coeficiente de fidelidade pode ser medido pelo histórico do cliente e na hora da recompra. A fidelidade deve ser considerada como estratégia e não como tática.

De acordo com Hirschman (1973), a fidelidade é importante devido ao poder de neutralizar, dentro de certos limites, a tendência que clientes mais conscientes de qualidade têm ao trocar de fornecedor. Como conseqüência da fidelidade, os clientes permanecem com a empresa mais tempo do que ficariam normalmente, na expectativa de uma melhora contínua, pois o custo de troca é alto e oneroso.

As estratégias de fidelidade para Reichheld (1996) baseiam-se em oito elementos: 
(1) Desenvolver uma proposição de valor superior para o cliente em relação às ofertas da concorrência.

(2) Encontrar o cliente certo identificando o cliente-alvo.

(3) Conquistar a fidelidade do cliente mantendo-o como um ativo e aumentando o valor ao longo do tempo.

(4) Encontrar os funcionários certos que compartilhem os valores da empresa.

(5) Conquistar a fidelidade do funcionário para que se reforce a criação de valor para o cliente.

(6) Ganhar vantagem de custos por meio da maior produtividade gerada pela maior fidelidade do cliente e do funcionário.

(7) Encontrar os investidores certos para estabilizar os sistemas de negócios e poder responder às ameaças competitivas.

(8) Conquistar a fidelidade do investidor.

O atendimento personalizado leva a uma diferenciação junto aos clientes. McGoldrick (1990) ressalta que o incremento de serviços vem se tornando importante diferencial entre as empresas. Conclui que 91\% dos clientes não voltam a comprar em um lugar no qual tenham sido mal atendidos e $70 \%$ dos clientes pagariam mais pelo produto caso percebessem um serviço melhor.

De acordo com Smith (2001), o marketing de relacionamento utiliza programas formais para construir relacionamentos que podem ser cultivados para gerar receitas marginais por meio de maior participação no bolso do cliente. Esse relacionamento formal pode ser por meio de um benefício especial dado ao cliente, em que ele sente receber tratamento especial e diferenciado. A fidelidade seria um estágio superior, no qual o relacionamento não se baseia apenas em programas formais e recompensas.

Criar um relacionamento pela Internet é mais que manter o número de acessos elevado. Engloba política de e-mails responsável (respostas adequadas e enviadas no máximo 48 horas depois de recebidas), maior interatividade com os compradores e usuários (listas de discussão, listas de distribuição, fórum de debate e chats), promoções, serviços inovadores e produtos adequados ao público-alvo, dentre outras soluções. 
A fidelidade eletrônica é gerada a partir de uma estratégia minuciosa de construção de relacionamentos com clientes. Para isso, exige-se que, no mínimo, o site opere com eficiência e seja objetivo.

De acordo com Giangrande (1999), adotar um marketing de relacionamento implica que a organização se dedique ao estabelecimento, manutenção e constante melhoria das relações com seus clientes - internos ou externos - com finalidade de lucro mútuo, de modo que os objetivos das partes envolvidas sejam atingidos.

De acordo com Reedy et al (2000) o marketing de relacionamento pode abranger ou influenciar quatro oportunidades de interação de clientes efetivos ou possíveis:

o Atração de clientes: uma presença informativa e inovadora na Web pode atrair novos clientes.

o Retenção de clientes: por meio de atendimento contínuo e com qualidade.

o Extensão de clientes: introdução de novos produtos ou serviços.

o Seleção de clientes: clientes de maior valor e mais lucrativos devem ser selecionados como preferenciais.

Portanto, o desafio atual é passar de um modelo centrado no produto para um modelo centrado no cliente. O uso de tecnologias de comércio eletrônico e a correta avaliação da adoção da tecnologia colaboram para manter a lealdade dos clientes, reunindo as informações e tornando os processos mais ágeis. Esse é um fator de diferencial competitivo que fortalece as marcas próprias e cria operações organizacionais eficientes (Seybold e Marshak, 2000).

\subsection{Estratégias organizacionais}

Estratégia é o plano que integra as principais metas, políticas e ações de uma organização de forma e coerente, colaborando na ordenação e alocação de recursos. Define a escala dnegócios em que a empresa deve se envolver e qual contribuição econômica e não econômica que pretende fornecer aos seus acionistas, funcionários e comunidade (Andrews apud Mintzberg e Quinn, 1998). 
Decisões estratégicas são aquelas que determinam a direção geral de um empreendimento. Os critérios para estratégias eficientes, de acordo com Quinn (apud Mintzberg e Quinn, 1998), devem abranger objetivos claros e diretos.

Para Quinn e Hilmer (apud Mintzberg e Quinn, 1998), pode-se, além de escolher individualmente cada estratégia, combiná-las:

- concentrando os próprios recursos da empresa em um conjunto de "essências competitivas”, as quais podem proporcionar valor adicional para os clientes;

- terceirizando, estrategicamente, as atividades nas quais a organização não necessita de estratégias críticas nem de capacidades especiais.

Os benefícios de combinar com sucesso as duas abordagens são alavancar os recursos e maximizar os retornos sobre os recursos internos ao concentrar investimentos e energias no que a empresa faz melhor. Para Mintzberg (apud Mintzberg e Quinn, 1998), as essências competitivas precisam ser sustentadas e aprimoradas como a chave para o futuro da organização. As competências podem ser combinadas de várias maneiras, por exemplo: por meio de joint ventures ou de outras formas de alianças estratégicas com sócios, acordos de licenciamentos, franchising e contratos de longo prazo.

Alianças estratégicas são cooperações voluntárias nas quais as organizações combinam recursos para aumentar sua força no ambiente competitivo (Gulati e Singh 1998). Essas alianças são organizadas de diversas formas a partir de contratos, joint ventures, participação acionária e outros. Para os autores, apesar do crescimento explosivo das alianças, elas estão associadas a riscos e incertezas. As necessidades organizacionais e suas capacidades são multifacetadas e diferentes entre si.

A aquisição de informações corretas é difícil de obter antes da conclusão da aliança ser iniciada. Em muitos casos, informações confidenciais relevantes para a definição da aliança estratégica não estão acessíveis. Uma segunda fonte de incerteza e de risco baseia-se na imprevisibilidade de atitude dos agentes. Uma mudança imprevista no ambiente competitivo pode levar a alterações nas necessidades das organizações e na orientação das alianças.

Bloch, Pigneur e Segev (1996, apud Albertin, 2000) apresentam que os sistemas de comércio eletrônico irão se tornar um dos componentes da imagem da marca dos produtos. A 
contribuição de uma imagem de marca é um dos principais interesses de algumas indústrias, principalmente daquelas com produtos tipo commodity ou com forte competição.

De acordo com a bibliografia levantada, a marca, a gestão e a operação são variáveis estratégicas que influenciam diretamente a organização.

\subsubsection{Marca como elemento estratégico}

Marca é um nome, símbolo ou representação, ou uma combinação desses elementos, que pretende identificar os produtos ou serviços, diferenciando-os da concorrência.

De acordo com Souza e Nemer (1993), as principais funções das marcas registradas são distinguir os produtos e serviços de uma empresa, indicar a fonte ou origem de produtos e serviços e representar o valor da organização, servindo como indicativo de seus produtos e serviços.

A marca é um meio de assegurar um nível de qualidade e de reduzir o risco da compra por seus atributos percebidos e associados ao produto ou empresa.

A não-utilização da marca, ou uso de marca genérica, geralmente utilizada em commodities de pouca ou nenhuma diferenciação, acarreta em custos menores de embalagem e de divulgação. Como vantagens do uso de marcas para os fabricantes, Souza e Nemer (1993:15) citam:

- proteção do produto contra imitação;

- diferenciação, identificação e localização do produto no ponto-de-venda;

- marca que satisfaz estimula a recompra;

- boas marcas podem gerar lealdade;

- marcas famosas permitem margens altas;

- $\quad$ as marcas permitem a segmentação. 
Fazendo um comparativo do uso da marca pela Internet com sistemas de distribuição pelo correio e catálogos apresentados pelos autores Souza e Nemer (1993), podemos citar como vantagens desse sistema:

- cobertura de vendas teoricamente ilimitada;

- eliminação dos custos fixos de distribuição direta (despesas com o ponto-de-venda);

- informações detalhadas sobre o produto ou serviço;

- $\quad$ possibilidade de personalização da oferta ao cliente;

- veículo suplementar de comunicação e vendas.

Algumas desvantagens são:

- restrições dos consumidores à compra de produtos com base numa página de web site;

- dificuldade dos consumidores em mudar os hábitos de compra.

Alguns autores, alertam que o reconhecimento da marca não basta para garantir a sobrevivência de uma empresa. Páginas eletrônicas que oferecem um bom serviço, com funcionamento sem problemas, experiência de compra agradável e entrega no prazo dão ao consumidor uma boa razão para voltar. Portanto, sites mais focados em serviços são mais eficazes do que os de preço baixo.

Para os autores, Hamel e Prahalad (1995), uma marca confiável é uma garantia de que o novo produto ou o serviço terá alto padrão de desempenho. Para os autores, o objetivo de uma banner brand é ajudar os clientes a transferir a confiança construída por meio da experiência positiva com um dos produtos da empresa para outros produtos que a empresa ofereça ou tencione oferecer. Defendem que os alicerces da corporação são as competências específicas da organização. Elas sustentam a liderança do produto, e suas banner brand(s) são o teto.

Na economia digital, o cliente informado consegue, de maneira rápida, informações sobre qualidade, características e preços de produtos desejados. Marcas que contavam com ineficiência de informação para comunicar valor inevitavelmente sofrerão um declínio no valor de sua marca. A projeção da imagem da qualidade deve ser de modo aberto, honesto e informal. O principal valor de um nome de marca é baseado na percepção dessa marca pelo consumidor, criada pelas informações que ele obtém, tanto do vendedor quanto de recursos de 
terceiros. Essas características fazem com que haja necessidade das estratégias de preço e de marca evoluírem e mudarem.

Desse modo, as marcas tornam-se opções estratégicas das empresas. Com elas, pode-se fortalecer a imagem da organização, aumentar a possibilidade de oferta diferenciada, oferecer diferenciação não baseada em preço e a utilização como instrumento de divulgação da organização. Entretanto, de acordo com Lazzarini, Neves e Chaddad (2000), produtos de maior especificidade devem continuar sendo transacionados por meio de contratos ou de integração vertical (produzir o próprio produto), e pode-se esperar, também, maior padronização dos produtos como forma de capturar os benefícios trazidos pela Internet.

A marca é um elemento estratégico importante, que contribui no sentido de predispor os clientes a considerar novos produtos e de transmitir aos clientes uma mensagem de segurança e de suporte.

\subsubsection{Processos organizacionais}

Processos organizacionais definem como as tarefas e procedimentos serão realizados. Com a utilização e adoção do comércio eletrônico, os processos tradicionais são alterados. A reengenharia torna-se uma ferramenta importante para reformular a empresa.

Seybold e Marshak (2000) alertam para o fato de que o uso do comércio eletrônico e sua correta adoção colaboram para processos mais ágeis e para operações organizacionais eficientes.

Para os autores Hamel e Prahalad (1995), a competição do futuro não será entre produtos, mas sim interempresas e suas operações. As razões disso são que a competição deve ser da corporação e não apenas de cada unidade de negócio; além disso, as competências necessárias para ter acesso às novas oportunidades podem estar espalhadas pelas unidades de negócios, cabendo à empresa de organizá-las; por último, o investimento e o tempo necessários para desenvolver as novas competências podem sobrecarregar recursos de uma única área de negócios. Nesse ponto, os autores defendem que criar o futuro exige que a empresa desenvolva novas competências essenciais, as quais normalmente transcendem à perspectiva de uma única área de negócios. 
Os autores também alertam sobre a necessidade de reunir e de harmonizar tecnologias altamente díspares entre si, de administrar um processo detalhado de definição de padrões, de estabelecer alianças com fornecedores de produtos complementares, de cooptar rivais em potencial e de ter acesso a mais ampla variedade possível de canais de distribuição.

Para Hamel e Prahalad (1995), toda empresa tem uma arquitetura de informação (tanto hard a infra-estrutura de tecnologia da informação - quanto soft - os padrões predominantes de comunicação interpessoal e interunidade). Para projetar a arquitetura de informações, a empresa precisa decidir quem deve se comunicar com quem, sobre o quê, com que freqüência e de que forma. Para construir uma arquitetura estratégica, é necessário conhecer os benefícios a ser oferecidos aos clientes, saber quais serão as competências essenciais necessárias para criar esses benefícios e descobrir como a interface com o cliente terá de mudar a fim de permitir o acesso dos clientes aos benefícios de forma mais eficaz.

As competências essenciais são as habilidades que permitem à empresa oferecer um benefício fundamental ao cliente, ou seja, constituem a aprendizagem coletiva na organização, especialmente a respeito de como coordenar diversas habilidades de produção e como integrar múltiplas tecnologias. Para ser qualificada como competência essencial, uma capacidade precisa ser competitivamente única. Nesse ponto, destaca-se a importância de construir, conscientemente, banner brands (marcas propagandas) que abranjam diversos produtos e negócios e que ajudem os clientes a transferir as experiências positivas dos produtos conhecidos para os novos.

Em Hammer, os processos organizacionais constituem uma das características principais do sistema empresarial. Para o autor Aldrich (2000), a era digital proporciona, além dos valores tradicionais - preço, qualidade e marca -, os valores tempo e conteúdo. O valor conteúdo refere-se à combinação de dois elementos: “produtos” e "serviços”. Ao comprar um produto, recebe-se um componente tangível (por exemplo: produto e embalagem) e um intangível (por exemplo: informação, atendimento personalizado e serviço de atendimento customizado).

O fluxo livre de informações encoraja maior demanda do cliente para produtos personalizados que atendam seus requisitos individuais. Essa personalização levará a numerosas e complexas configurações de produtos e de preços. Para o autor, as empresas poderão aproveitar seus bancos de dados para determinar preços variados para cada cliente individualmente, com base em suas estimativas sobre sensibilidade de preços para cada cliente, e vender-lhe mais produto. 
Seybold e Marshak (2000) citam que, dentro da reestruturação dos processos organizacionais, as empresas normalmente passam por cinco estágios distintos em suas iniciativas de comércio eletrônico:

1. Fornecer informações sobre a empresa e os produtos: organizações que possuem site na Web com objetivo de fornecer informações de marketing, produtos e dados sobre a empresa.

2. Fornecer suporte ao cliente e possibilitar transações: possibilitar sistemas automatizados ao cliente em que ele mesmo obtenha as informações desejadas, como verificação do status de seu pedido, recebimento do pagamento, saldo devido e execução de transações básicas.

3. Dar suporte às transações eletrônicas: possibilitar aos clientes adquirir produtos e serviços, no estágio de transações pela $W e b$, sem os recursos tradicionais, sem problemas de segurança e sem falhas. Ter acesso a todas as informações necessárias para que tome a decisão de compra.

4. Personalizar as interações com os clientes: personalizar a Web para cada cliente a fim de manter seu interesse, de forma que, quando voltar, por exemplo, será cumprimentado pelo nome, poderá consultar seu histórico, serão oferecidos produtos de seu interesse;

5. Fomentar o sentimento de comunidade entre os clientes, uma vez estabelecido um nível de confiança e de relacionamento pessoal com cada cliente usando as ferramentas eletrônicas. Isso é sinônimo de criar trocas de experiências, dar dicas e ter clubes de uso.

Com base nesse modelo progressivo, a Internet e a Web são utilizadas como plataformas para desenvolver aplicativos que interagem com o cliente. Informações são integradas, facilitando a criação de bancos de dados e de bases de conhecimento.

Uma descrição clara dos processos organizacionais colabora para a melhor definição do comércio eletrônico e sua adoção. A reengenharia possui papel fundamental de colaboração para criar um ambiente favorável na obtenção de resultados. 


\subsubsection{Gestão}

Com as novas tecnologias e mudanças constantes inerentes aos processos virtuais, a gestão organizacional torna-se um fator relevante para um diferencial competitivo. Em Hammer (1996), a gestão organizacional é uma das características importantes do sistema empresarial.

Para Nolan e Croson (1996), o primeiro desafio da gestão é entender o que precisa ser feito e, posteriormente, formular e compartilhar com a empresa uma visão de transformação.

Segundo Scott-Morton e Allen (1994 apud Turban, 2000), a gestão e os processos de negócios são componentes essenciais da organização.

Trope (1999) avalia a importância da gestão descentralizada versus a centralizada nas organizações com processos virtuais. Em uma organização com gestão centralizada e com várias unidades espalhadas geograficamente, os tomadores de decisão ficam prejudicados, em função do grande número de decisões a tomar e das deficiências da comunicação humana. Como vantagem da centralização, cita a maior uniformidade das diretrizes e normas. A descentralização da gestão pode ser vantajosa, na medida em que delega o poder de decisão e identifica os indivíduos do processo.

Moore (1996) enfatiza a necessidade de liderança e de gestão organizacional e sua importância para a transição suave entre os papéis de abandono dos velhos comportamentos ultrapassados e de adoção de novos procedimentos. A partir disso, é importante citar a reengenharia como um fator diferencial.

\subsubsection{Reengenharia}

A definição de reengenharia por Currid (1995), Hammer e Stanton (1995) é o repensar e o reprojetar os processos empresariais e a estrutura organizacional para produzir melhorias drásticas em desempenho. O desempenho, nesse caso, pode ser medido de várias formas, como menores custos, maior velocidade e maior precisão, e varia de acordo com a necessidade de cada organização. Para Manganelli e Klein (995), a reengenharia é o redesenho rápido e radical de processos de negócios estratégicos que agregam valor - e dos 
sistemas, das políticas e da estrutura organizacional que os sustentam -, a fim de otimizar os fluxos de trabalho e a produtividade em uma organização.

A reengenharia é, para Davenport (1994), a adoção de alguma coisa inovadora. Presume-se que o objetivo da introdução de algo inovador num processo seja provocar uma mudança importante, radical. Distingue-se da melhoria de processos, que visa a um nível inferior de mudança.

Processos, de acordo com Hammer (1996) e Hammer e Stanton (1995), é a palavra-chave, sendo um conjunto de atividades, do início ao fim, que, juntas, criam valor para o cliente. Por exemplo, o atendimento de pedidos é um processo que envolve uma série de tarefas, como verificação de crédito, baixa do pedido do estoque, empacotamento dos produtos e outros. Nenhuma dessas atividades, isoladamente, representa o menor interesse ou valor para o cliente. A única preocupação do cliente é com o resultado final, o bem entregue, o que cria com a soma total de todas as atividades relacionadas. Pode-se dizer que é por meio dos processos que as empresas criam valor para seus clientes.

Nas organizações baseadas em processos (Currid, 1995), a reengenharia permite que uma única pessoa, às vezes com auxílio da automação e da tecnologia da informação, possa fazer a mesma tarefa antes executada por várias pessoas. A tecnologia de informação é um habilitador e um implementador da mudança de processos (Davenport, 1994). As oportunidades da tecnologia da informação incluem a automação (eliminação da mão-de-obra humana num processo), a seqüência (modificação na seqüência de um processo ou a realização de tarefas em paralelo) a geografia (a habilitação de um processo para que opere efetivamente a grandes distâncias) e a desintermediação (eliminação de intermediários no processo). Os processos exigem da tecnologia da informação condições para a realização de mudanças, do mesmo modo que, para usar as capacidades da tecnologia de informação de maneira interfuncional é necessário uma visão de processos (Davenport, 1994).

Na reestruturação dos processos organizacionais, estes podem ser enquadrados, de acordo com Currid (1995), em três categorias: aerodinamização das operações, integração dos processos, unificação das funções e, por último, transformação da companhia. O grau de mudança depende da categoria em que se enquadra o projeto de reengenharia. Independentemente da categoria, a empresa certamente sofrerá grandes transformações em termos de pessoal, de métodos de trabalho e de tecnologia. As operações que têm por objetivo 
aerodinamizar os processos de uma companhia, em geral, visam apenas simplificar esses processos sem alterar sua natureza.

Um dos métodos mais utilizados pela reengenharia é o de integrar dois ou mais processos, substituindo-os por um processo unificado que, na maioria das vezes, envolve várias funções e vários departamentos. Algumas organizações optam pela reengenharia de forma radical, ou seja, transformando-a. Pode-se dizer, de acordo com Christensen (2000), que a reengenharia e a correta avaliação dos processos colaboram para transformar os inputs de tecnologia em output de maior valor.

Nas organizações em que se está adotando o comércio eletrônico, é necessário repensar o trabalho realizado, eliminado-se o trabalho desnecessário. Hammer e Stanton (1995) alertam contra um erro comum, que é tentar realizar a reengenharia sem uma liderança forte e comprometida.

Outro fator-chave para o sucesso da reengenharia é a equipe, ou grupo de pessoas que trabalham em direção a um conjunto comum de objetivos (Currid, 1995; Hammer, 1995). Com a mudança de um processo, mudam também as tarefas e, conseqüentemente, a habilidade requerida da equipe é diferente. Novas tarefas exigem que as pessoas sejam gerenciadas de uma forma nova.

As etapas básicas da reengenharia são (Currid, 1995): definição de objetivos, análise dos processos existentes, invenção de novas formas e trabalho e implementação de novos processos. Para isso, certas tecnologias básicas são essenciais para o sucesso dos projetos de reengenharia. Para Currid (1995), as três tecnologias fundamentais que podem ser consideradas como base para todas as outras são: redes de computador, bases de dados e ferramentas eletrônicas.

Os processos na interface com o cliente são muito importantes para o sucesso de uma organização (Davenport, 1994). São essenciais para a satisfação do cliente e para a eficiência do processo. Uma das novas ferramentas de interface é o comércio eletrônico, sendo utilizado como ferramenta de intercâmbio de dados comerciais (Currid, 1995). A reengenharia para a utilização do comércio eletrônico apresenta várias vantagens, tais como: redução de custos, processamento mais rápido dos dados, melhor atendimento ao cliente e serviços especiais, como a customização ao cliente (Davenport, 1994). 
Os problemas associados a essa atividade são: adoção de padrões (padronização) diferentes nas organizações dificultando o intercâmbio de dados e o uso de programas. Privacidade e segurança são duas preocupações para as companhias que se preparam para compartilhar dados eletronicamente com outras empresas (Currid, 1995).

Davenport (1994) lembra que é difícil selecionar processos que devem ser reprojetados e isolar processos a ser descritos A fabricação deve ser vista separadamente ou como parte do gerenciamento de vendas? Todas as arquiteturas de processos permitem ajustes e acomodações, e a escolha dos processos por áreas é motivada, em parte, pela conveniência.

As possibilidades de reengenharia nos processos de contato com os clientes, no gerenciamento de vendas e pedidos são múltiplas. De acordo com Davenport (1994), o gerenciamento de pedidos, ou atendimento de pedidos, é a essência dos processos de vendas. Ele abrange desde a realização do pedido até o recebimento do pagamento pelo vendedor. O processo envolve a coordenação de atividades diversas como verificação de crédito, fabricação, logística e recebimento de contas.

Um ponto essencial para o sucesso organizacional e para seu comércio eletrônico consiste em processos bem projetados e em uma liderança comprometida com esse objetivo.

A seguir, são apresentados dois modelos que avaliam a adoção do comércio eletrônico às estratégias organizacionais.

2.6.5 Modelo de avaliação de Gulati e Garino (2000)1

Gulati e Garino (2000) avaliam o nível ideal de integração das tecnologias virtuais ao modelo tradicional de negócios de uma organização sob os aspectos marca, gerenciamento, operações e patrimônio líquido. Para os autores, deve-se "fazer o mix certo de bricks and clicks". Defendem que não é necessário manter as iniciativas de Internet separadas dos negócios tradicionais da empresa. Empresas mais inovadoras possuem tendência de integrar operações

\footnotetext{
${ }^{1}$ Ranjay Gulati é professor da Kellogg School of Management, Northwestern University, Estado de Illinois da área de gerência das organizações. Professor Nemmers na área de tecnologia e comércio eletrônico. Ph.D 1993 pela Universidade de Harvard. Jason Garino é membro da consultoria Boston Consulting Group.
} 
virtuais e físicas. A chave para o sucesso baseia-se em como o processo de integração é administrado.

Definindo-se o mix mais apropriado para a organização - integração total, parcial ou nenhuma - alcança-se uma melhor posição estratégica junto ao mercado.

Apesar das vantagens que a integração oferece, como o cross-marketing, a central única de atendimento ao cliente, troca de informações, integração de compras, os dados sobre o produto, o fornecedor, o cliente, o pedido e maior eficácia na distribuição, os autores acreditam que, em algumas organizações, o processo virtual deve ser mantido separado.

Para os autores, o modelo proposto não é uma decisão binária entre integrar ou separar. Existe uma gama imensa de combinações entre deixar os processos virtuais separados ou de maneira totalmente integrada. Cada indústria deve avaliar a partir de seus aspectos organizacionais, especificando quatro fatores: marca (brand), gestão (management), operações (operations) e patrimônio líquido do acionista (equity). A partir desses parâmetros, define-se o grau de integração do comércio eletrônico à sua operação tradicional.

O espectro abaixo é a proposta entre a total integração dos processos virtuais até sua total separação da empresa “física”. Cada organização deve avaliar o grau de integração mais eficaz no alcance de seus objetivos.
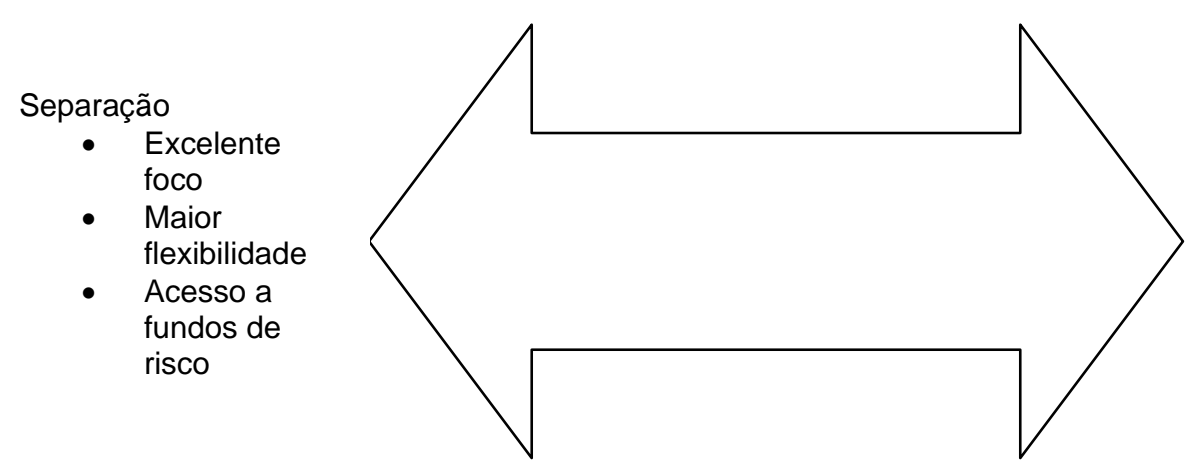

Integração

- Marcas estáveis

- Informações compartilhadas

- Alavancagem de compras

- Eficiência de distribuição 


$\begin{array}{llll}\text { Spin- } & \text { Parcerias } & \text { Joint } & \text { In-house } \\ \text { off } & \text { estratégicas } & \begin{array}{l}\text { division } \\ \text { ventures }\end{array} & \end{array}$

Fonte: R Gulati. e J. Garino, Get the right mix of bricks \& clicks, Harvard Business Review, May-June 2000, p. 110.

O desmembramento (spin-offs) de uma empresa é uma ferramenta estratégica. Trata-se, com freqüência, de uma boa maneira de efetuar o redimensionamento (resizing) de uma empresa em torno das capacidades que fazem mais sentido em termos competitivos (Tomasko, 1994).

Joint ventures, ou seja, o compartilhamento e a parceria estratégica, constituem uma maneira cada vez mais popular de contornar as limitações de uma estrutura organizacional existente (Tomasko, 1994).

Lientz e Rea (2001) alertam para o fato de que a integração dos processos leva à melhoria da agilidade da organização nos negócios virtuais, pressionando a gestão por velocidade. Em contrapartida, como problemas gerados citam que a implementação da estratégia pode ser prejudicial para os negócios regulares por ser capaz de gerar conflitos entre as transações de negócios tradicionais e o e-business, como, por exemplo, nos cronogramas de produção, no relacionamento com fornecedores e nas promoções. Para os autores, há níveis de separação, em que pode haver compartilhamento da estrutura de armazenamento, do serviço de suporte ao consumidor, de marketing, de recursos de tecnologia e de informação e outros sistemas. Uma vantagem da separação é a implementação do e-business sem os ranços da organização física, sendo que este não interferiria nos processos normais e tradicionais.

Existem diferentes combinações de permutação no espectro. A partir de um estudo cuidadoso dos aspectos organizacionais e das quatro dimensões que o compõem, as empresas podem formular estratégias virtuais que se adaptem melhor aos seus objetivos e a sua situação competitiva. 


\subsubsection{Primeira dimensão do modelo: marca}

A decisão de integrar as marcas ou de mantê-las segregadas está diretamente relacionada com confiança e flexibilidade. Uma marca reconhecida e respeitada da empresa, quando estendida à Internet, dá instantaneamente credibilidade ao Web site. Os clientes reconhecem imediatamente a marca e iniciam espontaneamente as transações comerciais. O medo de fraudes nas compras e o sentimento de falta de segurança, fatores freqüentemente inibidores do uso de compras on-line, serão menores. Normalmente, a integração de marcas cria um círculo comercial, em que os clientes virtuais são enviados para ser atendidos nas organizações e vice-versa.

Como desvantagem, a integração de marcas diminui a flexibilidade da organização, ou seja, a organização on-line pode ser forçada a oferecer o mesmo produto ao mesmo preço do processo tradicional, deixando alguns clientes insatisfeitos. Outra desvantagem é que uma marca compartilhada dificulta o alcance a outros segmentos de mercado.

\subsubsection{Segunda dimensão do modelo: gestão}

A separação das equipes de gerenciamento influencia tanto o modelo de negócio quanto os processos administrativos. Um time integrado estará mais alinhado à missão organizacional, aos objetivos estratégicos e na procura e exploração de sinergias. Haverá também maior compartilhamento de informações.

Equipes separadas são, freqüentemente, mais focadas em sua missão e possuem maior liberdade de inovação.

Nessa dimensão, pode-se também ter uma integração parcial de funções buscando maior liberdade para algumas áreas. A integração ou separação das equipes é uma questão sutil, cuja solução depende tanto das atitudes administrativas como do modelo de negócio da empresa. As empresas não precisam tomar uma decisão do tipo tudo ou nada. É possível integrar certas funções e deixar outras separadas. 


\subsubsection{Terceira dimensão do modelo: operações}

A decisão sobre a integração de operações deve ser baseada no grau de solidez dos sistemas de distribuição e de informação da empresa. A integração é capaz de proporcionar vantagens significativas na redução de custos, com sites mais completos e vantagens sobre competidores que atuam apenas no virtual ou do modo tradicional.

A separação de operações dá à organização a possibilidade de construir sistemas do nível estado da arte, ou seja, sistemas personalizados sem os ranços do sistema antigo, e de desenvolver meios sofisticados de distribuição específicos para atender o cliente da melhor forma.

A integração das operações possibilita à organização usar a Web para registrar pedidos, fornecer informações detalhadas sobre produtos, verificar estoques on-line, sugerir alternativas para produtos em falta, fazer vendas cruzadas de produtos complementares; acessar o histórico de informações do cliente e aumentar a produtividade de vendas.

\subsubsection{Quarta dimensão do modelo: composição do patrimônio líquido do acionista}

Manter a empresa independente ou optar por uma empresa subsidiária?

A integração permite que a empresa-mãe capte todo o valor de seu negócio na Internet.

A separação patrimonial pode servir para atrair e reter gerentes talentosos, para proporcionar acesso ao capital externo e para oferecer maior flexibilidade em parcerias com outras empresas. Manter uma participação em uma empresa independente da Internet pode ajudar o negócio tradicional a captar mais recursos no mercado de ações e a ter maior flexibilidade na criação de parcerias e alianças estratégicas. Como desvantagem, teria a necessidade de criar toda uma infra-estrutura de marketing, e o desenvolvimento de um conjunto de técnicas de gerenciamento.

Esse fator não será estudado pela dificuldade de se obter os dados necessários. 
2.6.6 Modelo de estrutura de Vasconcellos e Hemsley (1986)

Para os autores Vasconcellos e Hemsley, as estruturas organizacionais diferem quanto ao sistema de atividades, autoridade e comunicação. Essas diferenciações fazem com que possam ser classificados quanto a seus aspectos inovadores e tradicionais.

O sistema de atividades abrange todas as hierarquias, tanto as funções da alta administração, como os níveis intermediários e mais baixos. Ele resulta da definição de atividades de todos os integrantes da organização.

O sistema de autoridade é a definição do poder e sua distribuição pela organização, de modo que todos saibam suas obrigações e seu grau de subordinação.

O sistema de comunicação reflete como as informações fluem pela organização.

Para os autores, as organizações podem ser classificadas com estruturas tradicionais ou inovadoras a partir do grau de formalização de suas atividades, do nível de departamentalização, do padrão de comunicação, das unidades de comando e do grau de especialização.

O nível de formalização de uma organização é dado pelo grau de repetitividade e de estabilidade em que se opera a estrutura. Ambientes dinâmicos necessitam de flexibilidade nas ações; assim, as organizações inovadoras tendem a ter um nível mais baixo de formalização do que as organizações tradicionais.

As diversas alternativas de departamentalização - por exemplo, funcional, por centros de lucro, por projetos, por produtos, matricial, celulares ou novos empreendimentos - permitem maior ou menor especialização nas linhas de produtos. A partir de uma avaliação de cada alternativa e do setor que atua, cada tipo de departamentalização colabora para uma estrutura tradicional ou inovadora. Para cada um dos vários tipos de departamentalização, há dupla ou mesmo múltipla subordinação.

A repetitividade e o ambiente estável permitem alto nível de especialização nas estruturas tradicionais. Isso não é viável nas estruturas inovadoras. A alta taxa de mudança dificulta a especialização. 
Estruturas inovadoras tendem a utilizar comunicação horizontal, devido à necessidade de maior flexibilidade e agilidade.

Segue a Tabela 3, com a comparação entre organizações tradicionais e inovadoras quanto às características estruturais.

Tabela 3: Comparação entre organizações tradicionais e inovadoras

Tipos de organização

\begin{tabular}{|l|l|l|}
\hline \multicolumn{1}{|c|}{ Características estruturais } & \multicolumn{1}{|c|}{ Estruturas tradicionais } & \multicolumn{1}{c|}{ Estruturas inovadoras } \\
\hline Formalização & $\begin{array}{l}\text { Elevada: autoridade e } \\
\text { responsabilidade bem definidas. } \\
\text { Organogramas e manuais de } \\
\text { procedimentos }\end{array}$ & $\begin{array}{l}\text { Baixa. Dinamismo do ambiente } \\
\text { impede muita formalização }\end{array}$ \\
\hline Departamentalização & $\begin{array}{l}\text { Critérios tradicionais: funcional, } \\
\text { por processo, por cliente, } \\
\text { geográfica e por produto. }\end{array}$ & $\begin{array}{l}\text { Por projeto, matricial, por } \\
\text { centros de lucro, celular e } \\
\text { "novos empreendimentos" }\end{array}$ \\
\hline Unidade de comando & $\begin{array}{l}\text { Princípio da unidade de } \\
\text { comando é obedecido }\end{array}$ & $\begin{array}{l}\text { Unidade de comando não é } \\
\text { necessariamente obedecida }\end{array}$ \\
\hline Especialização & Relativamente mais elevada & Relativamente mais baixa \\
\hline Padrão de comunicação & Vertical & Vertical, horizontal e diagonal \\
\hline
\end{tabular}

Fonte: Vasconcellos, 1986, p. 29.

Hayes e Radosevich (1971 apud Vasconcellos) também comparam organizações “mecanicistas” (unidades de operação) e “orgânicas” (unidades inovadoras) avaliando o grau de tendência das organizações às formas tradicionais ou inovadoras.

Robbins (2000) descreve os dois tipos de organizações mecanicistas e orgânicas. A organização mecanicista é uma estrutura rígida e firmemente controlada. Caracteriza-se por alta especialização, extensa departamentalização, margens de controle estreitos, alta formalização, rede de comunicação limitada (comunicação descendente, principalmente) e pequena participação do baixo escalão na tomada de decisão. Na estrutura mecanicista, a especialização do trabalho gera cargos simples, rotineiros e padronizados, e existência de uma hierarquia formal de controle. 
A organização orgânica é uma forma oposta à mecanicista. Ela é adaptável, solta, com baixa formalização e flexível. A estrutura é achatada, utiliza equipes, possui pouca formalização e uma rede abrangente de informações (utilizando canais de comunicação lateral, ascendente e descendente) e envolve ativamente todos os funcionários nas tomadas de decisões (Tabela 4).

Tabela 4: Comparação entre unidades inovadoras e de operação

\begin{tabular}{|c|c|c|}
\hline Atributos & Unidades inovadoras & Unidades de operação \\
\hline $\begin{array}{l}\text { Orientação para resolução de } \\
\text { problemas }\end{array}$ & $\begin{array}{l}\text { Voltada para o ambiente externo } \\
\text { e para longo prazo }\end{array}$ & Interno e curto prazo \\
\hline Características da atividade & Não repetitiva e criativa & $\begin{array}{l}\text { Repetitiva, programável e } \\
\text { especificada nos mínimos } \\
\text { detalhes }\end{array}$ \\
\hline $\begin{array}{l}\text { Características das pessoas e } \\
\text { equipamentos }\end{array}$ & $\begin{array}{l}\text { Profissionais altamente } \\
\text { capacitados }\end{array}$ & $\begin{array}{l}\text { Fator humano menos habilitado, } \\
\text { processos automatizados }\end{array}$ \\
\hline Base do sistema de recompensa & $\begin{array}{l}\text { Auto-realização, curiosidade } \\
\text { intelectual, autonomia }\end{array}$ & $\begin{array}{l}\text { Econômica, status associado } \\
\text { com posição e títulos }\end{array}$ \\
\hline Estilo gerencial & $\begin{array}{l}\text { Participativo e decisões } \\
\text { conjuntas }\end{array}$ & $\begin{array}{l}\text { Dependência da autoridade } \\
\text { formal }\end{array}$ \\
\hline Processos de tomada de decisão & $\begin{array}{l}\text { Intuitivo, com eventuais estudos } \\
\text { analíticos }\end{array}$ & Uso de modelos quantitativos \\
\hline Atitude para com o risco & Assume riscos, tolera falhas & Risco reduzido ao mínimo \\
\hline $\begin{array}{l}\text { Sistemas de avaliação de } \\
\text { desempenho }\end{array}$ & $\begin{array}{l}\text { Auto-avaliação e avaliação pelos } \\
\text { pares }\end{array}$ & $\begin{array}{l}\text { Sistemas formais utilizando } \\
\text { padrões definidos por critérios } \\
\text { predeterminados }\end{array}$ \\
\hline Tecnologia utilizada & $\begin{array}{l}\text { Complexa, próxima às fronteiras } \\
\text { do conhecimento. }\end{array}$ & $\begin{array}{l}\text { Relativamente simples; } \\
\text { transferida e adaptada de grupos } \\
\text { inovadores de dentro ou de fora } \\
\text { da organização }\end{array}$ \\
\hline Base de coordenação & $\begin{array}{l}\text { Comunicação nos dois sentidos } \\
\text { e verbal }\end{array}$ & $\begin{array}{l}\text { Comunicação em um único } \\
\text { sentido, diretiva e geralmente } \\
\text { por meio de memorandos. }\end{array}$ \\
\hline
\end{tabular}

Fonte: Hayes e Radosevich, 1971 apud Vasconcellos, 1986, p. 22.

Boyett e Bouett (apud Turban, 2000) alertam para o fato de que as empresas precisam tanto de ações tradicionais quanto de atividades inovadoras. 
Uma estrutura organizacional define como são divididas, agrupadas e coordenadas as tarefas dos cargos (Robbins, 2000). Os seis elementos fundamentais na projeção da estrutura das organizações são: especialização do trabalho, departamentalização, cadeia de comando, margem de controle, centralização e descentralização e formalização. São descritos no Quadro 1.

\section{Quadro 1: Aspectos fundamentais para projeção da estrutura organizacional adequada}

\begin{tabular}{|l|c|}
\hline \multicolumn{1}{|c|}{ Perguntas } & As respostas são dadas por: \\
\hline $\begin{array}{l}\text { 1) Em que medida as tarefas são subdivididas em } \\
\text { cargos distintos? }\end{array}$ & Especialização do trabalho \\
\hline 2) Em que base os trabalhos serão agrupados? & Departamentalização \\
\hline $\begin{array}{l}\text { 3) A quem se reportam os indivíduos e os grupos? } \\
\text { eficiência e eficácia? }\end{array}$ & Cadeia de comando \\
\hline $\begin{array}{l}\text { 5) Em que reside a autoridade para a tomada de de controle } \\
\text { decisões? }\end{array}$ & Centralização e descentralização \\
\hline $\begin{array}{l}\text { 6) Em que medida haverá regras e regulamentos para } \\
\text { comandar os funcionários e gerentes? }\end{array}$ & Formalização \\
\hline
\end{tabular}

Fonte: Robbins, 2000, p.171.

Para Robbins (2000), a estrutura organizacional é um meio para ajudar a administração a alcançar seus objetivos. As combinações mais correntes entre estrutura e estratégia focalizam três dimensões desta última - inovação, minimização de custos e imitação - e a estrutura que melhor funcione com cada uma delas. Organizações que introduzem novos e importantes produtos ou serviços baseiam-se na estratégia de inovação. Aquelas que adotam uma estratégia de minimização de custos controlam seus custos rigidamente, evitando incorrer em inovações desnecessárias. Organizações que seguem uma estratégia de imitação tentam capitalizar o melhor de ambas as estratégias anteriores. Buscam minimizar riscos e maximizar as oportunidades de lucro. O Quadro 2 descreve a opção estrutural mais adequada a cada estratégia. 
Quadro 2: Proposição estratégia-estrutura

\begin{tabular}{|c|l|}
\hline Estratégia & \multicolumn{1}{|c|}{ Melhor opção estrutural } \\
\hline Inovação & $\begin{array}{l}\text { Orgânica: estrutura solta, baixa especialização, pouca } \\
\text { formalização, descentralização }\end{array}$ \\
\hline Minimização de custos & $\begin{array}{l}\text { Mecanicista: controle rígido, alta especialização do trabalho, } \\
\text { muita formalização, bastante centralização }\end{array}$ \\
\hline Imitação & $\begin{array}{l}\text { Mecanicista e orgânica: controles rígidos sobre atividades } \\
\text { correntes e controles mais soltos sobre novos } \\
\text { empreendimentos }\end{array}$ \\
\hline
\end{tabular}

Fonte: Robbins, 2000, p.180.

\section{MATERIAIS E MÉTODOS}

\subsection{Amostra}

É composta por três empresas do setor químico que atuam no segmento B2B e vendem produtos tipo commodities. As empresas escolhidas oferecem produtos tipo insumos industriais, que de acordo com KAPLAN e SAWHNEY (2000), são matérias primas ou componentes destinados a um processo de produção de outra indústria.

VASNETSOV (2000) justifica que empresas químicas que possuem produtos tipo commodities no comércio eletrônico possuem melhor posicionamento em relação aos produtos de especialidades no mercado B2B a partir de quatro critérios. O primeiro fator: sendo uma commoditie, a quantidade de especificações e diferenciações são reduzidas facilitando a negociação e compra. Em segundo, o produto é vendido em grande quantidade e utilizado por diferentes tipos de clientes em vários segmentos, o que permite atingir maior número de participantes. Em terceiro, os produtos tipo commodities possuem maior flexibilidade de preços. Por último, são produtos de fácil transporte, facilitando o processo de negociação e venda online. Por estes fatores, os produtos tipo commodities são mais fáceis de serem vendidos em tempo real. Os produtos tipo especialidades são, de acordo com o autor, 
vendidos em leilões reversos ou via vendas de catálogos exigindo maiores especificações e detalhamento.

Segundo uma pesquisa realizada pelo The Boston Consulting Group, conduzida por FREELAND e STIRTON (2000), as empresas já estabelecidas no "mundo real” estão bem posicionadas para serem bem sucedidas em comércio eletrônico pois já possuem as vantagens dos ativos críticos como marca forte, relacionamentos com clientes estabelecidos e sistemas de logística existentes.

Abaixo segue a apresentação das empresas pesquisadas e um breve histórico sobre as mesmas.

\subsubsection{Forlab Chitec}

A primeira empresa pesquisada foi a Forlab Chitec S.A. Fundada em 1954 no Rio de Janeiro. Possui filial em São Paulo e Belo Horizonte. É uma empresa importadora e distribuidora de insumos para a indústria farmacêutica humana e veterinária. Em 2001, o faturamento anual declarado foi de vinte e três milhões de reais, podendo ser considerada uma organização de grande porte apesar de possuir apenas cinqüenta e quatro funcionários. Como clientes podemos citar a Bayer S.A, Schering S.A e Bristol Meyer Squibb. Dentre os fornecedores: Merck, Basf, Noviant e o grupo Novartis.

\subsubsection{BCC Comercial Ltda.}

A segunda empresa pesquisada foi a Bcc Comercial Ltda. A empresa foi fundada em 2000 com sede em São Paulo e escritórios em Porto Alegre e Campinas. Atua no agenciamento de produtos químicos estrangeiros para o Brasil. Assim como a Forlab, a empresa importa e mantém estoque de produtos químicos para revenda no mercado nacional. Agencia tanto produtos tipo commodities como especialidades. Faturamento anual declarado em 2001 (valor em real) foi de $\mathrm{R} \$ 2.000 .000,00$ sendo considerado uma organização de grande porte apesar de possuir apenas oito funcionários. 


\subsubsection{Best Química}

A última empresa pesquisada foi a Best Química. Fundada em 1991 em São Paulo. Distribui produtos petroquímicos do tipo commodities para o mercado industrial em geral. Em 10 anos, aumentou suas vendas e o porte de suas instalações. De acordo com a empresa, investe no quadro de funcionários, treinamento, equipamentos e qualidade. Conta com 40 funcionários administrativos e operacionais. Os produtos vendidos são da linha de solvente tipo aguarrás, xileno e tolueno. O faturamento anual de 2002 foi de sessenta milhões de dólares.

\subsection{Método}

As estratégias organizacionais das empresas serão avaliadas através de questionários e entrevistas. A página de comércio eletrônico existente de cada empresa será analisada, como um meio de verificação dos recursos disponíveis, facilidade de acesso e disponibilidade dos dados. Será utilizado o método de estudo de caso. As empresas a serem estudadas serão determinadas de forma não probabilística e intencional.

\subsubsection{Estratégia de avaliação}

O grau de integração das tecnologias de comércio eletrônico às estratégias organizacionais depende das características organizacionais e de aspectos estruturais.

A organização será avaliada sob os aspectos inovadores e tradicionais com base no modelo de Vasconcellos e Hemsley (1986). Posteriormente será identificado como as variáveis do modelo de avaliação de integração de tecnologias de Gulati e Garino (2000) colaboram para a integração de processos virtuais ao modelo tradicional de negócio. A dimensão patrimônio líquido do acionista não será avaliada por impossibilidade de se obter facilmente esta informação.

Segue Figura 1 com estratégia de avaliação. 
Figura 1: Estratégia de avaliação da integração dos processos virtuais

\section{ESTRUTURA}

\begin{tabular}{|l|l|}
\hline TRADICIONAL & INOVADORA \\
\hline
\end{tabular}

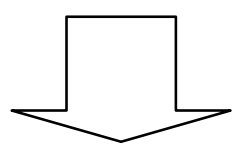

ANÁLISE DOS ASPECTOS ORGANIZACIONAIS MARCA

GESTÃO

OPERAÇÃO

DEFINIÇÃO DOS

PROCESSOS VIRTUAIS
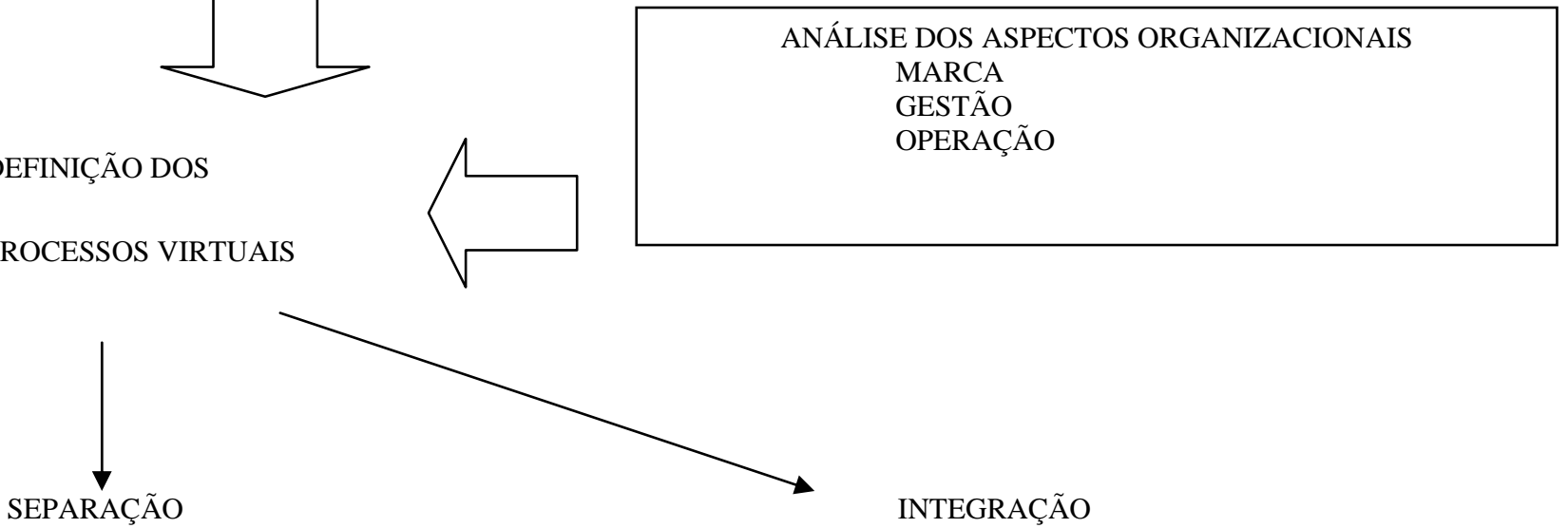

INTEGRAÇÃO

Fonte: autora (2002).

Sugiro você apresentar apenas o nome das variáveis que compõem este modelo. Não faz mal que sejam repetidas.

\subsubsection{Tipo de pesquisa}

O desenvolvimento do trabalho proposto baseou-se em dados primários a partir de um levantamento de dados qualitativos, de cunho exploratório.

Para melhor compreensão da escolha da metodologia utilizada, serão apresentados alguns conceitos básicos sobre a classificação da pesquisa. Para MATTAR (1997:77), os propósitos imediatos de uma pesquisa exploratória são de ganhar maior conhecimento sobre o tema, 
desenvolver hipóteses para serem testadas e aprofundar questões a serem estudadas. O objetivo não é a verificação das hipóteses, mas gerá-las, além de ampliar os conhecimentos sobre o problema em estudo (AAKER, KUMAR e DAY, 1998). Os dados qualitativos são coletados para melhor conhecer um assunto que não pode ser diretamente observado ou medido.

MINAYO (1992) lembra que as metodologias da pesquisa qualitativa são aquelas capazes de incorporar a questão do significado e da intencionalidade como inerentes aos atos, às relações e às estruturas sociais. Incorpora aspectos tanto subjetivos quanto objetivos da realidade, buscando explicações mais abrangentes e com profundidade. Para AKKER, KUMAR e DAY (1998) a pesquisa qualitativa de base exploratória procura definir um problema com maior detalhe, gerando novos conceitos e sugestões de hipóteses a serem testados em pesquisas subseqüentes.

A concepção da pesquisa, de acordo com MALHOTRA (1999:105), é uma estrutura ou planta para a realização do projeto de pesquisa. Detalha os procedimentos necessários à obtenção das informações indispensáveis para estruturar ou resolver problemas da pesquisa.

O trabalho será um estudo de caso. YIN (1995) define cinco componentes importantes em um estudo de caso que são: as questões de estudo devem estar relacionadas com os objetivos de determinar o "como" e o "por que”; as proposições do estudo que dirigem a atenção a alguma coisa que deva ser examinada; a unidade de análise definida; ligação lógica dos dados com a proposição e critérios claros para interpretar os dados. Apresenta assim, média amplitude e média profundidade, geralmente é utilizada quando há interesse em conhecer o inter-relacionamento entre as variáveis que ocasionam um fenômeno.

Como esta pesquisa será realizada uma única vez, seus resultados mostram um instantâneo do fenômeno estudado. É considerada uma pesquisa ocasional (ad-hoc).

A partir do exposto e em função de o tema escolhido ter sido pouco explorado no setor químico e conseqüentemente poucos trabalhos científicos terem sido realizados, esta dissertação terá cunho exploratório com base em estudo de caso.

\subsubsection{Instrumento de coleta de dados}


As formas de pesquisa a serem utilizadas são:

- Entrevistas individuais com o responsável pela área de vendas; o entrevistado responde perguntas abertas, garantindo maior confiabilidade nos dados obtidos, uma vez que o pesquisador pode esclarecer dívidas que poderiam surgir no questionário.

- Questionário estruturado, não disfarçado com predomínio de perguntas abertas: o próprio respondente lê a pergunta e a responde diretamente no instrumento de pesquisa, sem o auxílio de entrevistadores. A pesquisa por questionário será através de correio ou por e-mail, de acordo com a conveniência do respondente.

Será também utilizado o levantamento bibliográfico como um meio de coleta de dados.

Segundo MATTAR (1997) existem quatro diferentes fontes básicas de dados em pesquisa: o pesquisado, situações similares, pessoas que tenham informações sobre o pesquisado e dados disponíveis.

No processo de entrevista, as principais condições para o alcance de respostas satisfatórias e evitar erros de informação serão seguidas, como escolha de entrevistados cooperativos, correta explanação das perguntas de modo a completa compreensão destas e escolha dos respondentes aptos a responderem cada questão (AAKER, KUMAR e DAY, 1998).

A forma mais tradicional e corriqueira de obtenção de dados é através da comunicação com o detentor dos dados e sua principal característica é de que o dado é obtido através da declaração do próprio respondente (MATTAR 1997).

Este trabalho utilizará as seguintes fontes: pesquisado, pessoas que tenham informações sobre o pesquisado e dados disponíveis.

- Pesquisado: as empresas químicas escolhidas para o estudo;

- Pessoas que tenham informações sobre o pesquisado: ABIQUIM

- Dados disponíveis: bibliotecas e revistas especializadas.

As fontes de dados serão primárias ou diretas. Fontes primárias se caracterizam por nunca terem sido coletados, tabulados ou analisados. O método básico de coleta de dados será por questionamento verbal e escrito. 
O formulário de pesquisa foi desenvolvido a partir das variáveis de pesquisa originadas no modelo de referência.

Como vantagem do método da comunicação pode-se citar (MATTAR, 1997:159): mais versátil, mais rápido, menor custo e pode ser usado para obter a grande maioria dos tipos de dados. Como desvantagem: depende da boa vontade dos respondentes, depende da sinceridade do respondente, o instrumento de coleta ou a forma de coleta pode influenciar as respostas e ser menos preciso.

Na coleta de dados, o método da comunicação quanto ao grau de estruturação e disfarce será utilizado: estruturado não disfarçado e não estruturado não disfarçado.

Nos instrumentos que utilizam método estruturado não disfarçado, as perguntas são apresentadas exatamente com as mesmas palavras, sempre na mesma ordem e com as mesmas opções de respostas a todos os respondentes. O objetivo da padronização é procurar que todos respondam exatamente à mesma pergunta. As perguntas devem ser feitas de maneira a não induzir as respostas. Como vantagem: simplicidade de aplicação e facilidade de tabulação, análise e interpretação. Como desvantagem: dependem da boa vontade do respondente e a forma de coleta pode influenciar as respostas.

A abordagem não estruturada não disfarçada caracteriza-se por ter os propósitos do estudo claros aos respondentes, mas não há uma estruturação predefinida das perguntas e das respostas. As respostas são abertas e os respondentes são encorajados a expressar suas experiências e intenções. A técnica utilizada será a entrevista focalizada individual.

O método da comunicação quanto à forma de aplicação compreende entrevistas e questionários autopreenchidos. As entrevistas podem ser realizadas pessoalmente ou por telefone. Questionários autopreenchidos consistem em um instrumento de coleta de dados a ser lido e respondido diretamente pelos pesquisados, não havendo a figura do entrevistador. As formas de enviar e receber os questionários compreendem o uso de correio, inclusive eletrônico, fax e pessoalmente. Será utilizado um uso combinado das várias formas de comunicação.

As atividades de pesquisa consistem em realizar medições e, para isto, é necessário desenvolver instrumentos adequados para que as medidas realizadas tenham confiabilidade e validade. O processo de medição consiste em associar números a um objeto, que possa representar as quantidades de suas características ou atributos. 
Há quatro escalas básicas de medição, nominal, ordinal, intervalo e razão (Anexo A). Uma escala nominal é aquela onde os números servem apenas para nomear, identificar ou categorizar dados sobre objetos ou fatos. Na escala ordinal, os números servem para nomear, identificar e/ou categorizar, ordenar, segundo um processo de comparação em relação à determinada característica. A escala de intervalo indica a posição e quanto o objeto de estudo está distante em relação à determinada característica. Não permite concluir quanto à magnitude absoluta das medições. As escalas de razão possuem as mesmas propriedades das escalas de intervalo, com a vantagem de possuírem o zero absoluto. Em função disso, as medidas tomadas nestas escalas permitem concluir quanto à sua magnitude absoluta, além de informar a posição e quanto os objetos pesquisados estão distantes entre si em relação a determinada característica.

A coleta de dados através de entrevistas indica o caráter qualitativo deste estudo. Permite ao pesquisador uma melhor análise dos resultados e percepção das nuances do ambiente.

Não será utilizado procedimento estatístico para a análise das informações. Como a pesquisa é de cunho exploratório, não há intenção de estabelecer correlações entre variáveis. O objetivo é comparar os dados obtidos através das pesquisas com o referencial teórico, analisando-se cada variável de interesse com o conteúdo da literatura. A partir disto, formar hipóteses sobre o assunto.

\subsubsection{Aplicação do modelo}

A área escolhida para a pesquisa foi a área de vendas das empresas. As mesmas devem possuir algum tipo de comercialização eletrônica. Foi escolhida esta área pelo fato de os processos de interface com o cliente serem fatores essenciais para o sucesso de uma organização (DAVENPORT, 1994).

Foi esclarecido para os entrevistados que a pesquisa é de cunho acadêmico e os dados das empresas são de aspecto confidencial e não divulgável. Será também definido que as empresas serão categorizadas pelo setor que atuam, ou seja, vendas de especialidades e vendas de commodities. 
Além do setor em que atuam, as empresas e organizações podem ser classificadas pelo seu porte. Observa-se que o faturamento e o número de funcionários são muito usuais como critérios para classificação do porte e, portanto, foram considerados esses dois critérios.

O número de funcionários de uma organização é um dos fatores que traduz seu porte. De acordo com a ABIQUIM este parâmetro em conjunto com o faturamento colabora para a classificação do porte da organização.

Com base nos modelos foi elaborado um questionário que procura identificar a organização. Segue roteiro para identificação das variáveis.

\begin{tabular}{|c|l|}
\hline Número da questão & Objetivo \\
\hline De 1 a 3 & $\begin{array}{l}\text { Identificação da empresa. Informações sobre faturamento, número de } \\
\text { funcionários e produtos vendidos, histórico organizacional. }\end{array}$ \\
\hline 4 & $\begin{array}{l}\text { Identificação dos aspectos organizacionais com base no modelo de } \\
\text { VASCONCELLOS e HEMSLEY (1986) }\end{array}$ \\
\hline 5 & Identificação do setor de vendas \\
\hline 6 & $\begin{array}{l}\text { Avaliação das características organizacionais tradicionais e inovadoras } \\
\text { com base no modelo de VASCONCELLOS r HEMSLEY (1986) }\end{array}$ \\
\hline 7 & $\begin{array}{l}\text { Análise da gestão organizacional com base no modelo de GULATI e } \\
\text { GARINO (2000) }\end{array}$ \\
\hline 9 & $\begin{array}{l}\text { Identificar as operações organizacionais com base no modelo de } \\
\text { GULATI e GARINO (2000) }\end{array}$ \\
\hline Análise da marca com base no modelo de GULATI e GARINO (2000) \\
\hline
\end{tabular}

Foi realizada uma avaliação pessoal do web site, comparando-se o serviço oferecido com a pesquisa realizada. Foi avaliada a facilidade de acesso, disponibilidade de dados e os produtos oferecidos.

\section{ESTUDO DE CASOS}

\subsection{Forlab}


A empresa atua em dois segmentos: excipientes e princípios ativos. No setor de excipientes, representa empresas multinacionais com marcas fortes e reconhecidas, neste caso possui o papel de ter estoque local para atender a demanda contínua, pode ser considerado produto tipo especialidades.

De acordo com a empresa, na venda de princípios ativos, o cliente procura por preço versus qualidade, sem uma rígida fidelidade à marca ou fornecedor. O fator marca não é fator importante, podendo ser considerado como um produto tipo commoditie.

Para esta empresa será estudada a venda de princípios ativos. O objetivo da utilização do comércio eletrônico pela Forlab é integrar os processos das filias, agilizar a comunicação com os clientes, atender as necessidades do mercado, assim como facilitar a transação comercial e acesso a novos mercados. Para a comunicação e vendas utilizam-se do e-mail.

O web site da empresa é do tipo institucional, em português ou inglês, onde constam seus produtos, especificações técnicas e histórico da empresa. A página é estática, onde não há uma personalização para o cliente. Não utilizam nenhumas das ferramentas do marketing eletrônico.

Segundo a Forlab, houve dificuldades para a confecção do web site, pois as empresas de informática possuíam pouco conhecimento técnico sobre o setor químico, não sabiam como fornecer as características dos produtos técnicos de maneira clara e de fácil acesso e não conheciam a linguagem do setor, dificultando a comunicação. A confecção foi realizada a partir de instruções dadas pela diretoria e não houve a participação da equipe de vendas ou do químico responsável.

O departamento de vendas é segmentado por linha de produto.

A Forlab utiliza dois processos de vendas, o tradicional e via Internet.

No processo tradicional de vendas, os vendedores visitam os clientes com intervalos regulares, identificam a demanda, criam opções de compras diferenciadas e acompanham o que cada concorrente está oferecendo. Neste caso, os vendedores são responsáveis por verificar as necessidades de cada cliente e realizar a venda, o fator qualidade do produto e bom atendimento são variáveis de diferenciação.

No processo de vendas via Internet, o cliente está mais interessado em preço. De acordo com a gerente de vendas da Forlab, a marca dos princípios ativos não é um fator decisivo. $\mathrm{O}$ 
consumidor final não consegue identificar a matéria prima utilizado, assim produto que têm as especificações técnicas necessárias são largamente consumidos. Como já foi dito, o fator relevante neste caso é qualidade versus preço. Caso o produto atenda as especificações técnicas requisitadas, o fator preço decide a compra. Em muitos casos, o cliente não conhece o produto mas compra pela confiança em que a Forlab irá fornecer produtos de acordo com sua necessidade. Atualmente, a empresa procura criar uma imagem padrão de qualidade relacionada com confiança e flexibilidade, pois os clientes quando não conhecem o produto, confiam na recomendação do fornecedor.

Os princípios ativos, por não terem marcas reconhecidas são aprovadas pelos clientes a partir de testes químicos e aprovação de amostras. Estes devem atender às especificações químicas exigidas. Este é um fator restritivo, pois as marcas existentes não dão instantaneamente credibilidade ao web site (assumindo que a marca é reconhecida e respeitada) e não geram tráfego imediato de novos clientes. Outra grande limitação enfrentada para a realização do comércio eletrônico é a confiabilidade das informações técnicas sobre os produtos. Este problema acaba gerando a necessidade de visitas regulares ao cliente, criando um vínculo com estes. Para a Forlab, o site e o comércio eletrônico não geram confiabilidade e vendas, geram apenas acesso e comodidade.

A equipe de gestão da internet não é integrada à estrutura organizacional e existe pouco compartilhamento de informações. Não existem programas de educação e treinamento para a área de comércio eletrônico, assim como não existe uma pesquisa de avaliação das necessidades dos clientes na área do comércio eletrônico.

O estilo de gestão não se alterou com a criação de vendas via internet. Mas houve a reestruturação da área de vendas para que a nova ferramenta fosse incorporada à área. A orientação do departamento é para a resolução de problemas diários e rotineiros, foco no curto prazo.

As operações são independentes, não existe uma integração entre as várias áreas da organização como suprimento, estoque, cobrança e financeiro. O modelo de distribuição de produtos vendidos via comércio eletrônico não se diferencia do processo tradicional. A separação de operação deu à organização, possibilidade de construir um sistema personalizado para cada operação, completamente adequando às necessidades de cada departamento. Isto acaba gerando problemas gerenciais pois há duplicidade de funções e atividades assim como falta de comunicação interna gerando conflitos e desperdícios. 
A empresa possui uma baixa formalização com dinamismo em seu ambiente organizacional e extrema flexibilidade. A departamentalização é do tipo matricial por novos empreendimentos. A unidade de comando é obedecida, centralizadora e forte. Existe um rígido seguimento do princípio da unidade. O padrão de comunicação é vertical, através de memorandos, ou via email. Existe uma forte dependência da autoridade formal. As atividades exercidas pela empresa são repetitivas, coordenadas pelo manual de procedimentos.

O departamento de vendas é único, onde tanto as vendas tradicionais, como as realizadas pelo comércio eletrônico são coordenadas pela mesma equipe. Esta equipe de vendas é formada por profissionais pouco habilitadas para o processo virtual, inexistindo treinamento. $\mathrm{O}$ fator relevante para a contratação é o conhecimento técnico da área e dos produtos. Não existe um critério de avaliação diferenciado para as vendas via rede e os profissionais da empresa são avaliados de forma subjetiva pela diretoria.

Não houve alterações das marcas dos produtos oferecidas via internet, logo os produtos oferecidos na rede são os mesmos do processo tradicional. O mercado alvo pretendido pela internet era o mesmo do tradicional. Apesar disto, o poder de barganha do cliente é maior, fazendo com que o preço praticado pela internet seja inferior ao praticado pelos processos tradicionais.

\subsection{Resultados da BCC}

O objetivo na utilização do comércio eletrônico é minimizar erros no parte de logística, suporte e identificar novos clientes e potenciais mercados de vendas não explorados. Também utilizam o e-mail para comunicação e transações de negócios. Para a empresa o comércio eletrônico possibilita aos clientes a obtenção de informações sobre os produtos da organização, constituindo-se em um showroom 24 horas. O site foi construído como uma resposta à solicitação do mercado, mas não houve uma pesquisa para entender os clientes e avaliar o que os parceiros esperam do comércio eletrônico.

Atualmente o processo tradicional de vendas, onde o vendedor através do telefone ou visita tirava o pedido, está integrado com as novas tecnologias. Os clientes utilizam o e-mail como meio de comunicação e realização do comércio eletrônico, ou seja, a empresa recebe solicitações via internet, oferta os produtos aos seus clientes tradicionais e novos. Neste 
processo todos os funcionários estão envolvidos, tanto o pessoal de vendas quanto o pessoal técnico, porem a empresa possui dúvidas sobre seu site, quanto ser uma ferramenta de vendas ou apenas um site informativo/instrutivo, pois acreditam que o contato direto e pessoal com o cliente é parte fundamental para o sucesso da venda. Para a empresa a venda automática via um site pode possibilitar um contato com um número maior de clientes, porem tira a vantagem da aproximação para com o mesmo e a conseqüente compreensão de suas necessidades.

Existe a integração das informações com os canais de vendas o que possibilita a maior compreensão das necessidades do setor. Uma das dificuldades e limitações encontradas para a realização do comércio eletrônico é a necessidade de flexibilidade do sistema, para poder atender as necessidades específicas de cada cliente. Temem que o comercio eletrônico não seja capaz de atender a questões pontuais e que possa desmotivar o cliente a comprar deles. Acreditam que o contato pessoal seja fundamental e que a venda de produtos sem peculiaridades seja mais fácil de se vender no comercio eletrônico.

O modelo de distribuição dos produtos do processo tradicional é igual para atender o comércio eletrônico. O departamento de vendas é dividido por segmento de produtos (setor farma, setor veterinário, setor químico, setor agro, setor química especial), tendo cada um seu centro de custo independente. Não existe divisão por clientes, ou seja, existem clientes que são atendidos por dois gerentes de vendas, por utilizarem produtos de dois setores diferentes. Não existe separação regional, cada setor trabalha toda a área América Latina.

Não existem programas de educação e treinamento para a área de comércio eletrônico. A unidade de comando é centralizada, onde cada gerente setorial deve apresentar relatórios de vendas e desempenho duas vezes ao ano. O grau de especialização necessário para o cargo é baixo, não sendo necessários especialistas em cada área, porem se necessita um conhecimento generalizado de onde e como os produtos são utilizados.

A comunicação existente entre os departamentos e funções é do tipo diagonal, com alto grau de flexibilidade e em todos os sentidos. Para a empresa o alto grau de flexibilidade do departamento é um pré-requisito para sobrevivência da empresa, pois a rápida adaptação a novas regras de mercado é vital para de adequar as necessidades dos clientes.

O estilo de gestão não se alterou com o comércio eletrônico, assim como não houve reestruturação interna na empresa em virtude do negócio virtual. Para a empresa existe pouca 
relação do comércio eletrônico com a estratégia organizacional. Acreditam que o comércio eletrônico deverá ampliar as fronteiras, porém não significa aumento de vendas, pois o mesmo, como já mencionado, se baseia muito no contato pessoal. Outro fator positivo mencionado pela empresa seria a simplificação do processo de vendas, agilizando entregas e fluxo de informações.

O comércio eletrônico é integrado ao processo tradicional. O departamento dá ênfase na procura de soluções de problemas rotineiros com constante aperfeiçoamento do sistema.

Existem constantemente atividades criativas, mas pode-se dizer que a grande maioria das atividades do setor são rotineiras. A base do sistema de recompensa aos funcionários está fundamentada na geração de rentabilidade econômica.

Não houve alteração das marcas nos produtos oferecidas via internet. Os produtos oferecidos são os mesmos do processo tradicional e o mercado alvo pretendido pela internet era o mesmo do tradicional, sendo assim não há alteração do preço praticado pela internet e pelo praticado pelos processos tradicionais.

A equipe de vendas via internet é a mesma do processo tradicional. Os funcionários da área recebem treinamento para trabalhar via internet, mas os critérios de avaliação são iguais para os processos virtuais e tradicionais.

\subsection{Resultados da Best}

A empresa possui no próprio site um ícone para pedidos on-line, onde o cliente deve digitar seu nome, dados cadastrais e quantidade do produto solicitado. Esta página eletrônica é estática, não existindo personalizações ou reconhecimento do cliente.

O comércio eletrônico foi desenvolvido como um meio de atender de maneira eficiente seus clientes, atender a demanda do mercado e utilizar-se do catálogo na Web para mostrar seus produtos e instalações. Apesar disto não acreditam que gere receitas e novos clientes.

No processo tradicional de vendas, o cliente entra em contato com a empresa, e solicita os produtos existentes. Estes clientes são conquistados através das visitas realizadas pelos 
vendedores externos. No processo virtual, os clientes solicitam o produto pela página eletrônica, mas a venda sempre é confirmada via telefone por um vendedor interno.

De acordo com a empresa o mercado em que atuam não favorece ao modelo de comércio eletrônico. Citaram como dificuldade e limitações encontradas para a realização do comercio eletrônico a dificuldade de se alterar os processos tradicionais de venda, onde o cliente já conhece o procedimento e não utiliza o novo mecanismo.

O modelo de distribuição de produtos via Internet é o mesmo do processo tradicional. Não houve alteração do estilo de gestão e do departamento de vendas. O modelo organizacional existente antes da introdução do comércio eletrônico não foi reestruturado.

O programa de treinamento existente é voltado para atendimento a cliente e qualidade, não existindo programas de educação para a área de comércio eletrônico. As atividades são do tipo repetitivas com poucas atividades criativas. A equipe de vendas existente, ao ser contratada, já deve saber utilizar as ferramentas virtuais. Para a área, o grau de especialização para exercer a função necessária é baixo.

O departamento de vendas está dividido geograficamente, existindo dois gerentes responsáveis por preço e pesquisa de mercado. De acordo com a empresa, a unidade de comando é descentralizada, existindo uma comunicação diagonal, informal e alta flexibilidade.

Não houve alteração do mercado alvo com a introdução do comércio eletrônico, assim como não houve alteração das marcas e de preços nos produtos oferecidos via Internet, sendo os mesmos produtos oferecidos no processo tradicional.

\section{CONCLUSÕES}

A correta adoção do comércio eletrônico é um fator de diferenciação. Seu sucesso depende de vários fatores e de um posicionamento adequado. Uma empresa não se transforma só porque criou uma página eletrônica (site eletrônico). O sucesso exige repensar a forma como o trabalho está organizado e requer um novo posicionamento junto ao cliente, mudanças na comunicação interna e externa, nas tomada de decisões, no estilo operacional e no comportamento organizacional. 
Avaliamos três empresas paulistanas, que vendem commodities e sua estrutura de organização é tradicional. São empresas com alto faturamento, mas que possuem pequeno quadro de funcionários. As três integraram o comércio eletrônico ao processo de vendas já existente, mas não elaboraram nenhum tipo de estratégia de implantação.

Podemos avaliar a partir do modelo de Vasconcellos e Hemsley que a Forlab, a BCC e a Best possuem uma estrutura tradicional, onde a autoridade e responsabilidade são bem definidas, alta formalização, departamentalização por critérios tradicionais e autoridade bem definida. A base do sistema de recompensa é econômica, a comunicação é diretiva através de memorandos. A tecnologia do comércio eletrônico está sendo pouco incorporada à organização. A postura tecnológica da empresa é extremamente tradicional com poucas características inovadoras. O comércio eletrônico não alterou a estrutura organizacional. A relação de comércio eletrônico com a estratégia organizacional é baixa, onde o comércio eletrônico é apenas uma ferramenta de comunicação.

De acordo com o modelo de Gulati e Garino, os produtos que são vendidos pelas empresas estudadas são do tipo commodities e se estendem naturalmente pela Internet. não havendo a necessidade de alteração de nomes e marcas. A linha de produtos oferecidos pelo comércio eletrônico é o mesmo do processo tradicional, sendo que o mercado alvo é o mesmo. Não há uma política diferenciada de preços. A gestão da área de vendas é comum para as duas áreas, sendo que os profissionais devem possuir capacidade e experiência para administrar também o canal de Internet, sendo que não há critérios diferentes para avaliação das iniciativas do comércio eletrônico e da área comercial tradicional. O modelo de gestão se baseia no já existente processo tradicional. As operações são estreitamente interligadas onde o sistema de distribuição se integra perfeitamente a Internet.

A partir destas características levantadas, as empresas se enquadram no modelo estudado, que preconiza a integração das operações de comércio eletrônico ao processo tradicional. De acordo com os autores, as empresas mais inovadoras possuem tendência de integrar operações virtuais e físicas. Esta tendência também foi verificada pelas empresas com aspectos tradicionais.

O uso do comércio eletrônico pelas três empresas é baixo e a tecnologia utilizada é de baixa complexidade. Não houve alteração da estratégia organizacional com a utilização do comércio eletrônico. 
O uso do comércio eletrônico pelas empresas possui outros pontos em comum, que são:

- Divulgação do nome e informações da empresa

- Uso como meio de comunicação com seus clientes

- Oferecimento de um serviço adicional

Os entrevistados ressaltaram a importância da atuação dos vendedores na divulgação dos produtos, não acreditam que a Internet e o comércio eletrônico irão substituir os vendedores externos pois é importante o contato pessoal com o comprador.

A integração do processo eletrônico aproveita a estrutura organizacional já existente, suas operações de marketing e acesso à informação. As empresas não utilizam as possibilidades do marketing eletrônico para melhor avaliação de seus clientes e para a construção de um programa de comercialização. Assim como nenhuma das empresas pesquisadas possui uma estratégia clara para o comércio eletrônico e sua adoção não faz parte das estratégias organizacionais. Utilizam-na como uma extensão das ferramentas de vendas e marketing já existentes. Não exploram seu potencial e não desenvolvem formas de criar valor para os clientes em termos de produtos e serviços.

HAMEL e PRAHALAD (1995) já alertaram que o desenvolvimento de novas tecnologias exige mais do que um bom planejamento. O sucesso das atividades virtuais exige também uma cultura adequada (KANTER, 2001). Uma empresa não se transforma só devido à criação de uma home page. O sucesso da adoção do comércio eletrônico exige o repensar da forma como todo o trabalho está organizado e avaliação da postura organizacional. Isto não foi realizado nas organizações estudadas.

Não foi possível pesquisar uma organização de aspectos inovadores para verificar se existe uma tendência diferente de adoção do comércio eletrônico.

Podemos levantar a hipótese que organizações com aspectos tradicionais tendem a integração do comércio eletrônico aos seus processos já existentes. 


\section{LIMITAÇÕES E RECOMENDAÇÕES}

A metodologia escolhida, o estudo de caso, possui limitações, não podendo ter seus resultados generalizados. Outro fator limitante é o fato de se ter estudado apenas o setor químico sem focar nos clientes e fornecedores, que são fatores importantes na adoção do comércio eletrônico. O tempo disponível para a realização deste projeto foi um aspecto limitante.

Como sugestões para estudos futuros recomenda-se o estudo de outros participantes da cadeia de fornecimento do setor químico. O papel de cada um deles é importante para se entender o processo como um todo. É importante também estudar organizações com aspectos inovadores para verificar se existe uma tendência de adoção diferente do comércio eletrônico.

\section{BIBLIOGRAFIA UTILIZADA}

AAKER, D. A.; KUMAR, V.; DAY, G. S. Marketing Research. $6^{\text {st }}$ Edition. New York, John Wiley \& Sons Inc., 1998.

ALBERTIN, A.L. Comércio eletrônico, modelo, aspectos e contribuições de sua aplicação. $2^{\circ}$ edição, São Paulo: Editora Atlas, 2000.

ALBRECHT, K. Revolução nos serviços. São Paulo: Editora Pioneira, 1998.

AMIT, R. e ZOTT, C., Value Creation in E-Business. Strategic Management Journal, j. 22: 293520, 2001.

B2B MAGAZINE, B2B: O futuro é agora. Disponível em http://www.networkexpress.com.br/shop/shop.dll/noticias?Codigo=2236. Publicado em 12/1/2002. Consultado em 19 de Janeiro 2003.

BOABAID, P. P., Disponível em www.cybereconomist.ecn.br/portugues/downloud/boabaid.pdf Consultado dia 23 Maio 2003.

BRONDMO, H. P. Fidelização - como conquistar e manter clientes na era da Internet. São Paulo, Editora Futura, 2001. 
BROWN, S.A., CRM - Customer Relationship Management - uma ferramenta estratégica para o mundo e-business. São Paulo, $1^{\circ}$ edição, Makron Books Ltda, 2001.

BRUNER, R. E. et al. Marketing on-line - estratégias, melhores práticas e estudos de casos, São Paulo, Editora Futura, 2001.

BRUNO, M. A. C. Tecnologia e estratégia das empresas do setor químico: conceitos e tendências. Revista de Administração, São Paulo, v. 30, n. 2, p. 5-17, abril/junho, 1995.

BRUNO, M. A. C., Gestão da cooperação técnica entre empresas e estratégia empresarial: estudos de casos no setor químico. Tese apresentada à Faculdade de Economia, Administração e Contabilidade da Universidade de São Paulo para obtenção do título de doutor em Administração, 1995.

CARR, N. G., TI já não importa. Harvard Business Review América Latina, vol. 81, nº 5, p. 3037, Maio, 2003.

CARVAlHO, K., Comércio eletrônico. Construção Mercado, no 14, ano 55, p. 23-27, Editora Pini, Setembro 2002.

CHRISTENSEN, C. M., The Innovator's Dilemma, New York, HarperCollins Publishers Inc., 2000.

CONFEDERAÇÃO NACIONAL DA INDÚSTRIA (CNI). Metodologia de sondagem industrial. Disponível em www.cni.org.br/produtos/econ/ src/metodologia_sondagem.pdf acesso em: 19 de Janeiro 2003.

CRONIN, M.J., Fazendo Business via Internet: como a estrada eletrônica está transformando as empresas americanas, São Paulo, Editora Érica Ltda., 1995.

CRONIN, M.J., The Internet Strategy Handbook: lessons from the new frontier of business, Boston, Harvard Business School Press, 1986.

CURRID, C., Ferramentas para a Reengenharia. Rio de Janeiro, Distribuidora Record de Serviços de Imprensa S.A., 1995.

DAVENPORT, T. H. et al., Como elas conhecem tão bem os clientes. HSM Management, vol. 27, p. 106 -112, Julho - Agosto, 2001. 
DAVENPORT, T. H., Reengenharia de processos: como inovar na empresa através da tecnologia da informação. Rio de Janeiro, Editora Campus Ltda., 1994.

De SOUZA MINAYO, M.C. O desafio do conhecimento: pesquisa qualitativa em saúde. São Paulo, Hucitec/abrasco Ltda, 1992.

DICKSON, G. W. e DeSANCTIS, G., Information Technology and the future enterprise. Prentice Hall, 2001.

DRUCKER, P., Além da Revolução da Informação. HSM Management, vol. 18, p. 48-55, Janeiro Fevereiro, 2000.

ELLSWORTH, J. H., ELLSWORTH, M.V. Marketing on the Internet, New York, John Wiley \& Sons Inc., 1997.

FREELAND, G. D. e STIRTON, S., Organizing for comércio eletrônico. The Boston Consulting Group Inc. Disponível em:

www.bcg.com/publications/files/organizing\%20Ecommerce\%20Apr\%2000.pdf. Acesso em 19 de Janeiro 2003.

GIANGRANDE, V. (Coords.). Marketing de Relacionamento no Varejo. São Paulo: Editora Atlas, Provar, 1999.

Giangrande, V. Marketing de Relacionamento e o Papel do Ombudsman. In ANGELO, C. F., GIANGRANDE, V. (Coords.). Marketing de Relacionamento no Varejo, São Paulo, Editora Atlas S.A., Provar, 1999.

GOLDMAN SACHS, Internet Economics, a thinker’s guide. Economist, $1^{\circ}$ de Abril, 2000.

GRÖNROOS, C., Service management and marketing: managing the moments of thruth in service competition. Massachusetts, Lexington Books, 1990.

GULATI, R. e GARINO, J., Get the right mix of Bricks \& Clicks. Harvard Business Review, vol. 78, nº 3, p. 107 - 114, May - June, 2000.

GULATI, R. E SINGH, H., The Architecture of Cooperation: Managing Coordination Costs and Appropriation Concerns in Strategic Alliances Disponível em: http://www.ranjaygulati.com/art/gulatisingh.pdf Consultado dia 13/07/2002

HAMEL, G., PRAHALAD, C. K. Competindo pelo futuro. Rio de Janeiro: Editora Campus, 1995. 
HAMMER, M. e STANTON, S. A., A Revolução da Reengenharia - um guia prático. Rio de Janeiro, Editora Campus Ltda., 1995.

HAMMER, M., Além da Reengenharia. Rio de Janeiro, Editora Campus Ltda., 1997.

HAMMOND, K., O comércio eletrônico até 2010. HSM Management, vol. 32, p. 38-52, Maio Junho, 2002.

HIRSCHMAN, A., Saída, voz e fidelidade São Paulo, Editora Perspectiva S.A., 1973.

KALAKOTA, R., ROBINSON, M. e-Business: estratégias para alcançar o sucesso no mundo digital. $2^{\mathrm{a}}$. Edição. Porto Alegre, RS: Bookman Artmed Editora S.A. 2002.

KANTER, R. M., Os dez pecados capitais da primeira geração. HSM Management, vol. 27, p. 6272, Julho - Agosto, 2001.

KAPLAN, S. e SAWHNEY, M., E-hubs: os mercados interempresariais. HSM Management, vol. 23, p. 110-116, Novembro - Dezembro, 2000.

KAPLAN, S., SAWHNEY,M., E-hubs: os novos mercados interempresariais. HSM Management, vol. 23, p. 110-116, Novembro - Dezembro, 2000.

KEARNEY, A. T., Três idéias de marketing. HSM Management, vol. 27, p. 82 - 92, Julho - Agosto, 2001.

KOMENAR, M. Eletronic marketing. New York: John Wiley \& Sons, 1997.

KOTLER, P., Administração de marketing - análise, planejamento, implementação e controle. São Paulo, Editora Atlas S.A., 1994.

LAUDON, K. C. e LAUDON, J. P. Management Information Systems. $4^{\circ}$ Edition, New Jersey, Prentice Hall, Inc., 1996.

LAZZARINI,S. G., NEVES, M. F. e CHADDAD, F. R., Impactos da Internet nas transações entre empresas Preços Agrícolas, ano XIX, nº 160, p. 48 - 49, USP/ESALQ - DEAS e CEPEA, Fevereiro, 2000.

MALHOTRA, N. K., Pesquisa de marketing - uma orientação aplicada. $3^{\circ}$ edição, Porto Alegre, Artmed Editora Ltda., 1999. 
MANGANELLI, R. L. e KLEIN, M. M., Manual de Reengenharia: um guia passo a passo para a transformação da sua empresa. Rio de Janeiro, Editora Campus Ltda., 1995.

MATTAR NETO, J. A., Metodologia Científica na Era da Informática, São Paulo, Editora Saraiva, 2002.

MATTAR, F.N., Pesquisa de Marketing, 4ºdição, volume1, São Paulo, Editora Atlas, 1997.

McGOLDRICK, P. J. Retail Marketing. Londres, McGraw-Hill, 1990

McKENNA, R, As cinco regras do novo marketing. HSM Management, vol. 22, p. 14 - 22, Setembro - Outubro, 2000.

McKENNA, R. Marketing de Relacionamento. Rio de Janeiro: Editora Campus, 1992.

MINTZBERG, H. e QUINN, J. B., O Processo da Estratégia, $3^{\circ}$ edição, Porto Alegre, Editora Bookman, 1998.

MOORE, G. A., Dentro do furacão. São Paulo, Editora Futura, 1996.

NAKAMURA, R. R., Comércio eletrônico na Internet: Fácil de entender. São Paulo, Editora Érica, 2001.

NOLAN, R. L. e CROSCON, D. C., Destruição criativa. Rio de Janeiro, Editora Campus Ltda., 1995.

O’CONNEL, B., B2B.com cashing on the business-to-business comércio eletrônico bonanza. Holbrook, MA, Adams Media Corporation, 2000.

PEARSON, M. Attractors: Building mountains in the flat landscape of the World Wide Web. Director, July, 1998, p. 81.

PEPPERS, D.; ROGERS, M. The one to one future. New York: Currency-Doubleday, 1993.

REEDY, J., SCHULLO, S., KENNETH, Z. Marketing Eletrônico - a integração de recursos eletrônicos ao processo de marketing. Porto Alegre, Artmed Editora Ltda, 2000.

REICHHELD, F. F., A Estratégia da Fidelidade. Rio de Janeiro, Editora Campus Ltda. 1996.

ROBBINS, S. P., Administração mudanças e perspectivas. São Paulo, Editora Saraiva, 2000. 
SAIKOVITCH, V. L., O uso estratégico da Internet pelas livrarias brasileiras. Tese apresentada ao Departamento de Administração da FEA/USP para obtenção do título de doutor em Administração, 2000.

SAP, Disponível em www.sap.com/brazil/company/perspectiva/1500/pag-56-57-58.pdf Consultado dia 23 Maio 2003.

SEBRAE, Informações básicas sobre classificação das indústrias. Disponível em www.sebrae.org.br acesso em: 19 Jan. 2003.

SEYBOLD, P.B. \& MARSHAK, R.T. Clientes.com: como criar estratégia empresarial para a internet que proporcione lucros reais. São Paulo: Makron Books, 2000.

SILVA, E., Indústrias praticam pouco $\quad$ o $\quad$ B2B. Disponível em http://www.networkexpress.com.br/shop/shop.dll/noticias?Codigo=832. Fonte: TCI Net com data de publicação em 26/06/2001. Consultado em 19 de Janeiro de 2003.

SLYWOTZKY, A. J. e MORRISON, D. J., How digital is your business? New York, Crown Publishing Group, 2000.

SMITH, E. R. Fidelidade e-loyalty - como usar a Internet para fidelizar clientes. Rio de Janeiro: Editora Campus, 2001, p. 29.

SOUZA, M. G. de e NEMER, A., Marca \& Distribuição. São Paulo, Makron Books Editora Ltda., 1993.

STALK JR, G., HOUT, T. M. Competindo contra o tempo. Rio de Janeiro: Editora Campus, 1990.

SVIOLA, J. J., SHAPIRO, B. P. Mantendo clientes. São Paulo: Makron Books do Brasil Editora Ltda, 1995.

TAPSCOTT, D.; LOWY, A.; TICOLL, D., Plano de ação para uma economia digital: prosperando na nova era do e-business, São Paulo, Makron Books do Brasil Editora Ltda., 1998.

TIGRE, P. B., Disponível em www.ie.ufrj.br/redesist/ntf2/nt\%20paulo.pdf Consultado dia 23 Maio 2003.

TOMASKO, R. M., Rethinking - repensando as corporações. São Paulo, Makron Books do Brasil Editora Ltda., 1994. 
TROPE, A., Organização virtual: impactos do teletrabalho nas organizações. Rio de Janeiro, Qualitymark Editora Ltda, 1999.

TURBAN, E. et al., Eletronic commerce a managerial perspective. New Jersey, Prentice Hall Inc., 2000.

VASCONCELLOS, E. P. G. e HEMSLEY, J. R., Estrutura das Organizações: estruturas tradicionais, estruturas para inovação, estrutura matricial. São Paulo, Livraria Pioneira Editora, 1986.

VASCONCELLOS, E. P. G., Gerenciamento da Tecnologia: um instrumento para a competitividade empresarial. São Paulo, Editora Edgard Blücher Ltda, 1992.

VASNETSOV, S., Disponível em www.chemconnect.com/22601.html - 14k. Consultado dia 08 Julho 2002.

VASNETSOV, S., Disponível em www.industryweek.com/CurrentArticles/ asp/articles.asp?ArticleId=1110 - 22k. Consultado dia 08 de Julho 2002.

VASNETSOV, S., Comércio eletrônico: a net gain or loss for the chemical Industry? Chemical Management Review, volume 2, issue nº 2, p. 8 - 19, Houston, TX, March - April, 2000.

VAVRA, T. G., Marketing de Relacionamento. São Paulo, Editora Atlas, 1993.

WEI, J.; RUSSEL, T.W.F.; SWARTZLANDER, M.W., The structure of the chemical processing industries: functions and economics. New York, McGraw-Hill, 1979.

WEIL, P. e VITALE, R., Place to space - migrating to e-business models. Harvard Business School Publishing Corporation, USA, 2001.

\section{BIBLIOGRAFIA CONSULTADA}

AMOR, D. A (R)Evolução do E-Business. São Paulo, SP: Makron Books, 2001.

AMOR, D. The e-Business (R)Evolution: Living and Working in na Interconnected World. $1^{\text {st }}$ Edition. Upper Saddle River, NJ: Prentice Hall, 2000. 
ANGELO, C. F., GIANGRANDE, V., et al. Marketing de Relacionamento no Varejo, São Paulo, Editora Atlas S.A., 1999.

CARLSON, D. Modelagem de Aplicações Xml com Uml - Aplicações Práticas de E-business. São Paulo, SP: Makron Books, 2001.

FRANCO JR., Carlos F. e-Business: Manual para o desenvolvimento e implementação de sistemas e tecnologia da Informação. São Paulo, Editora Atlas, 2002.

FRANCO JR., Carlos F. e-Business: Tecnologia da informação e negócios na Internet, São Paulo, Editora Atlas, 2001.

FRANK, R. E. e GREEN, P. E., Métodos Quantitativos em Marketing. São Paulo: Editora Atlas S.A., 1973.

HACKER, S. L., Ambiente competitivo e comportamento do mercado farmacêutico veterinário no Brasil. Dissertação apresentada à Escola Superior de Agricultura ESALQ/USP para obtenção do título de mestre em Ciências, 2000.

HOFACKER, C.F. Internet Marketing. $3^{\text {rd }}$ Edition. New York, NY: J. Willey\&Sons, Inc., 2001.

INMON, W.H. Como construir o data warehouse. $2^{\circ}$ edição. Rio de Janeiro: Editora Campus, 1997.

THElmA, R. \& VEloso, A. A Hora da Recompensa. São Paulo, Cobra Editora \& Marketing, 1999.

TICOLL, D., Polêmica sobre a Web. HSM Management, vol. 28, p. 18-23, Setembro - Outubro, 2001.

VASCONCELLOS, E. P. G. e MURITIBA, S. N., Estrutura organizacional como diferencial competitivo em negócios eletrônicos: estudo de caso em uma empresa do ramo de Internet. Trabalho apresentado no Encontro da Associação Nacional de Programas de Pós-Graduação em Administração, Salvador, ANPAD, 2002.

VASCONCELLOS, E. P. G. e MURITIBA, S. N., OLIVEIRA, P. M., Modelo de análise dos graus de utilização do negócio eletrônico em empresas virtuais e tradicionais: um estudo de caso dos casos das livrarias Amazon.com e Barnes \& Nobles. Trabalho apresentado no Seminário em Administração, SEMEAD, 2001. 
ZILBER, S. N., Fatores críticos para o desenho e implantação de e-business por empresas tradicionais. Tese apresentada ao Departamento de Administração da FEA/USP para obtenção do título de doutor em Administração, 2002. 


\section{ANEXOS}

\subsection{Anexo 1: Roteiro do questionário}

O questionário será realizado através de entrevistas, para maior entendimento das perguntas.

\section{1) Identificação da empresa}

Nome da empresa:

Nome do entrevistado:

Endereço da empresa:

Cep.: Cidade: Estado: São Paulo

Tel.: Fax.: Data

Faturamento anual declarado em 2001 (valor em real):

Ano de fundação e histórico organizacional:

2- Por favor, assinalar com um $\mathrm{X}$ a alternativa correspondente à empresa:

Esta empresa vende:

(1) Produtos tipo especialidades

(2) Produtos tipo commodities

(3) Produtos tipo commodities e especialidades

3- Qual a quantidade total de funcionários da organização e seu faturamento:

Número de funcionários

Porte

\begin{tabular}{|l|l|l|}
\hline (1) de 0 a 9 & Micro & \\
\hline (2) Entre 10 e 99 funcionários & Pequena & \\
\hline
\end{tabular}




\begin{tabular}{|l|l|l|}
\hline (3) Entre 100 e 499 funcionários & Média & \\
\hline (4) Mais que 500 funcionários & Grande & \\
\hline
\end{tabular}

Tabela - Classificação do porte da empresa segundo o núemro de funcioários

Fonte: Sistema de Cadastro Industrial da FIESP

Faixa de Faturamento em 1.000 R\$

\begin{tabular}{|l|l|}
\hline (1) de 0 a 120.000 & \\
\hline (2) Entre 120.000 a 720.000 & \\
\hline (3) Entre 720.001 a 1.500 .000 & \\
\hline (4) Entre 1.500 .001 a 3.000 .000 & \\
\hline (5) Entre 3.000.001 a 6.000 .000 & \\
\hline (6) Acima de 6.000 .001 & \\
\hline
\end{tabular}

Tabela - Faixa de Faturamento

Fonte: Anuário do IBGE 1997

\section{4- Identificação de aspectos organizacionais}

\begin{tabular}{|l|l|l|}
\hline Características & Sim & Não \\
\hline 3.1 Há uma clara definição de cargos e funções & & \\
\hline 3.2 Existem manuais de procedimentos escritos & & \\
\hline $\begin{array}{l}\text { 3.3 A responsabilidade da função de vendas via Internet está } \\
\text { limitada ao cargo }\end{array}$ & & \\
\hline 3.4 A autoridade do setor de vendas é limitada & & \\
\hline 3.5 A unidade de comando de vendas é centralizada & & \\
\hline 3.6 Existe um padrão de atividades repetitivas & & \\
\hline 3.7 Existem constantemente atividades criativas & & \\
\hline 3.8 Os processos são formais e pré-determinados & & \\
\hline 3.9 O estilo gerencial é participativo onde as decisões são conjuntas & & \\
\hline 3.10 A comunicação é através de memorandos e formalizada & & \\
\hline 3.11 O cadastro de clientes e o processo de compras são integrados & & \\
\hline 3.12 Vendas e estoque são integrados & & \\
\hline $\begin{array}{l}\text { 3.13 Quando ocorre algum imprevisto, o sistema permite } \\
\text { flexibilidade do operador de vendas }\end{array}$ & \\
\hline 3.14 Existe no we site a possibilidade do cliente se cadastrar para & & \\
\hline
\end{tabular}




\begin{tabular}{|l|l|}
\hline receber maiores informações sobre a empresa ou produtos? & \\
\hline 3.15 Existe controle de fluxo de clientes visitados & \\
\hline $\begin{array}{l}\text { 3.16 Os funcionários estão contentes com as mudanças e novos } \\
\text { processos via Internet? }\end{array}$ & \\
\hline
\end{tabular}

\section{5- Identificação do setor de vendas}

Qual o objetivo na utilização do comércio eletrônico?

Descrever o processo de vendas tradicional e o processo de vendas via Internet

Quais as dificuldades encontradas na confecção do site e na realização do comércio eletrônico? Houve a participação do grupo de vendas? Do químico responsável?

Existe a integração das informações com os canais de vendas?

Quais as dificuldades e limitações encontradas para a realização do comércio eletrônico?

Existe um modelo diferente de distribuição dos produtos do processo tradicional para atender o comércio eletrônico?

Descrever produtos comercializados, número de itens, universo de clientes, custo dos produtos vendidos, quantidade de vendas e modo de negociação.

Qual a porcentagem de vendas via internet?

\section{6- Identificação das características estruturais inovadoras e tradicionais da organização}

Existem programas de educação e treinamento para a área de comércio eletrônico? Caso existam, explicar como são realizados.

Existe uma pesquisa que entenda os clientes e o que os parceiros esperam do comércio eletrônico?

Favor descrever o departamento de vendas (busca de identificar se está organizado por processo, função, cliente, geográfica, produto, projeto, matricial, centro de lucros, celular ou novos empreendimentos).

Descrever a unidade de comando (ex. forte, centralizada)

Qual o grau de especialização necessário para o cargo?

Definir modo de comunicação existente entre os departamentos e funções (vertical, horizontal, diagonal). Comunicação em um único sentido, diretiva e geralmente através de memorandos?

Descrever o grau de flexibilidade do departamento e das funções de acordo com as mudanças ambientais de mercado externas e internas. 


\section{7- Análise da gestão organizacional}

Foi criado um estilo de gestão baseado no comércio eletrônico?

Houve alguma reestruturação interna na empresa em virtude do negócio virtual?

Qual a relação de comércio eletrônico com a estratégia organizacional? Definir o objetivo da empresa e missão do comércio eletrônico.

O grau de autoridade do departamento de vendas por comércio eletrônico é diferente do tradicional?

\section{8- Avaliação da operação organizacional}

Como foi realizada a integração do comércio eletrônico aos processos atuais?

Como as atividades de comércio eletrônico afetaram a estrutura organizacional?

Como se dá a integração do comércio eletrônico às outras áreas da empresa?

O comércio eletrônico é integrado ou separado do processo tradicional?

O departamento dá ênfase na procura de soluções de longo prazo ou nas soluções de problemas rotineiros?

Existe um padrão para atividades repetitivas ou a existência constante de atividades criativas?

Os profissionais do departamento são altamente capacitados para novos processos?

A base do sistema de recompensa aos funcionários está baseada na geração de rentabilidade econômica?

Estilo gerencial participativo onde as decisões são conjuntas?

Os clientes são receptivos aos novos procedimentos?

\section{9- Marca}

Houve alteração das marcas nos produtos oferecidas via internet? Descrever processo.

Os produtos oferecidos são os mesmos do processo tradicional?

O mercado alvo pretendido pela internet é o mesmo do tradicional?

O preço praticado pela internet é o mesmo praticado pelos processos tradicionais? 
A equipe de vendas via internet é a mesma do processo tradicional? Os funcionários da área recebem treinamento para trabalhar via internet? Os critérios de avaliação são diferentes para os processos virtuais e tradicionais?

Existe um sistema de sugestão de alternativas para produtos em falta?

\subsection{Anexo 2: Modelo das cartas de apresentação}

À

BEST QUIMICA S.A

Tel 4393-9800

A/C Sra. Fernando Mariano

À

FORLAB CHITEC S.A COM INTERNACIONAL

Tel 3277-0488

A/C Sr. Sylvia Poetscher

À

BCC COMERCIAL LRDA

Tel.: (11) 5561-3288 Fax.: (11) 5533-5130

A/C Sr. Robin Hermans

São Paulo, 01 de Julho 2003

Prezados Senhores

Sou mestranda da Faculdade de Economia, Administração e Contabilidade da Universidade de São Paulo - FEA/USP e estou realizando um estudo sobre o uso comercial da Internet pelo setor químico do Estado de São Paulo, cujo principal objetivo é identificar como foi a adoção do comércio eletrônico à estrutura organizacional. 
Venho através desta solicitar a valiosa contribuição de sua empresa na busca destas informações. Essa etapa consiste na coleta de informações através de um questionário/entrevista com a(s) pessoa(s) responsável(eis) pela utilização/adoção do comércio eletrônico no setor de vendas.

Agradeço antecipadamente pela atenção dispensada

Atenciosamente

Sibylle Sophie Hacker

9.3 Anexo 3: Características das escalas básicas de medição

\begin{tabular}{|c|c|c|c|}
\hline ESCALA & CARACTERÍSTICAS & $\begin{array}{l}\text { USO EM } \\
\text { MARKETING }\end{array}$ & $\begin{array}{l}\text { ESTATÍSTICAS } \\
\text { POSSÍVEIS }\end{array}$ \\
\hline Nominal & $\begin{array}{l}\text { Os números servem apenas } \\
\text { para nomear, identificar } \\
\text { e/ou classificar dados sobre } \\
\text { pessoas, objetos ou fatos. } \\
\text { Com escalas nominais, a } \\
\text { única operação possível é a } \\
\text { contagem, e por isso, a } \\
\text { moda é a única medida de } \\
\text { tendência central que pode } \\
\text { ser calculada. }\end{array}$ & $\begin{array}{l}\text { Marcas, sexo, } \\
\text { raças, cores, } \\
\text { região, uso/não } \\
\text { uso e a toda } \\
\text { variável que se } \\
\text { possa associar } \\
\text { números para } \\
\text { identificar. }\end{array}$ & $\begin{array}{l}\text { Moda, percentagens, } \\
\text { teste binomial, teste } \\
\text { Qui-quadrado, } \\
\text { Mcnemar, Cochran Q }\end{array}$ \\
\hline Ordinal & $\begin{array}{l}\text { Os números servem para } \\
\text { nomear, identificar, } \\
\text { categorizar e ordenar, } \\
\text { segundo um processo de } \\
\text { comparação de uma } \\
\text { determinada característica. } \\
\text { Esta escala permite } \\
\text { identificar a preferência por }\end{array}$ & $\begin{array}{l}\text { Atitudes, } \\
\text { preferências, } \\
\text { opiniões, classe } \\
\text { social, ocupação. }\end{array}$ & $\begin{array}{l}\text { Medianas, quartis, } \\
\text { decis, percentis, teste } \\
\text { Mann-Whitney, teste } \\
\text { U, Kruskal Wallis, } \\
\text { correlação de postos. }\end{array}$ \\
\hline
\end{tabular}




\begin{tabular}{|c|c|c|c|}
\hline & $\begin{array}{l}\text { uma marca, mas não quão } \\
\text { melhor é em relação à outra. }\end{array}$ & & \\
\hline Intervalo & $\begin{array}{l}\text { Os intervalos entre os } \\
\text { números indicam a posição } \\
\text { e quanto as pessoas, objetos } \\
\text { ou fatos estão distantes } \\
\text { entre si em relação à } \\
\text { determinada característica. } \\
\text { É possível comparar } \\
\text { diferenças entre medições, } \\
\text { mas não é possível concluir } \\
\text { quanto à magnitude } \\
\text { absoluta das medições, pois } \\
\text { não há um zero absoluto. }\end{array}$ & $\begin{array}{l}\text { Atitudes, opiniões, } \\
\text { conscientização, } \\
\text { preferências, } \\
\text { número índice. }\end{array}$ & $\begin{array}{l}\text { Média, intervalo, } \\
\text { amplitude total, } \\
\text { amplitude média, } \\
\text { desvio médio, } \\
\text { variância, desvio } \\
\text { padrão, teste A, teste } \\
\text { T, análise da } \\
\text { variância, correlação } \\
\text { de produto - } \\
\text { momento. }\end{array}$ \\
\hline Razão & $\begin{array}{l}\text { As escalas razão possuem } \\
\text { as mesmas propriedades das } \\
\text { escalas de intervalo, com a } \\
\text { vantagem de possuir zero } \\
\text { absoluto. É possível } \\
\text { concluir a magnitude } \\
\text { absoluta das medidas e } \\
\text { informar a posição que o } \\
\text { objeto, pessoa ou fato está } \\
\text { de uma determinada } \\
\text { característica. }\end{array}$ & $\begin{array}{l}\text { Idade, preço, } \\
\text { número de } \\
\text { consumidores, } \\
\text { volume de vendas, } \\
\text { renda, patrimônio. }\end{array}$ & $\begin{array}{l}\text { Todos os itens } \\
\text { anteriores e mais } \\
\text { média geométrica, } \\
\text { média harmônica e } \\
\text { coeficiente de } \\
\text { variação. }\end{array}$ \\
\hline
\end{tabular}

Fonte: MATTAR, 1997, p. 193.

9.4 Anexo 4: Quadro sinopse de identificação dos aspectos organizacionais da Forlab 


\begin{tabular}{|l|l|l|}
\hline 3.1 Há uma clara definição de cargos e funções & & $\mathrm{X}$ \\
\hline 3.2 Existem manuais de procedimentos escritos & $\mathrm{X}$ & \\
\hline $\begin{array}{l}\text { 3.3 A responsabilidade da função de vendas via Internet está } \\
\text { limitada ao cargo }\end{array}$ & $\mathrm{X}$ \\
\hline 3.4 A autoridade do setor de vendas é limitada & $\mathrm{X}$ & \\
\hline 3.5 A unidade de comando de vendas é centralizada & $\mathrm{X}$ & \\
\hline 3.6 Existe um padrão de atividades repetitivas & $\mathrm{X}$ & \\
\hline 3.7 Existem constantemente atividades criativas & & $\mathrm{X}$ \\
\hline 3.8 Os processos são formais e pré-determinados & $\mathrm{X}$ \\
\hline 3.9 O estilo gerencial é participativo onde as decisões são conjuntas & & $\mathrm{X}$ \\
\hline 3.10 A comunicação é através de memorandos e formalizada & $\mathrm{X}$ & \\
\hline 3.11 O cadastro de clientes e o processo de compras são integrados & $\mathrm{X}$ & \\
\hline 3.12 Vendas e estoque são integrados & $\mathrm{X}$ & \\
\hline $\begin{array}{l}\text { 3.13 Quando ocorre algum imprevisto, o sistema permite } \\
\text { flexibilidade do operador de vendas }\end{array}$ & $\mathrm{X}$ & \\
\hline $\begin{array}{l}\text { 3.14 Existe no web site a possibilidade do cliente se cadastrar para } \\
\text { receber maiores informações sobre a empresa ou produtos? }\end{array}$ & $\mathrm{X}$ & \\
\hline 3.15 Existe controle de fluxo de clientes visitados & & $\mathrm{X}$ \\
\hline 3.16 Os clientes são receptivos aos novos procedimentos? & $\mathrm{X}$ & \\
\hline
\end{tabular}

\subsection{Anexo 5: Quadro sinopse de identificação dos aspectos organizacionais da BCC}

\begin{tabular}{|l|l|l|}
\hline Características & Sim & Não \\
\hline 3.1 Há uma clara definição de cargos e funções & $\mathrm{X}$ & \\
\hline 3.2 Existem manuais de procedimentos escritos & & $\mathrm{X}$ \\
\hline $\begin{array}{l}\text { 3.3 A responsabilidade da função de vendas via Internet está } \\
\text { limitada ao cargo }\end{array}$ & $\mathrm{X}$ \\
\hline 3.4 A autoridade do setor de vendas é limitada & & $\mathrm{X}$ \\
\hline 3.5 A unidade de comando de vendas é centralizada & $\mathrm{X}$ & \\
\hline 3.6 Existe um padrão de atividades repetitivas & $\mathrm{X}$ & \\
\hline 3.7 Existem constantemente atividades criativas & & $\mathrm{X}$ \\
\hline 3.8 Os processos são formais e pré-determinados & $\mathrm{X}$ & \\
\hline 3.9 O estilo gerencial é participativo onde as decisões são conjuntas & & $\mathrm{X}$ \\
\hline 3.10 A comunicação é através de memorandos e formalizada & $\mathrm{X}$ \\
\hline 3.11 O cadastro de clientes e o processo de compras são integrados & $\mathrm{X}$ & \\
\hline 3.12 Vendas e estoque são integrados & $\mathrm{X}$ & \\
\hline $\begin{array}{l}\text { 3.13 Quando ocorre algum imprevisto, o sistema permite } \\
\text { flexibilidade do operador de vendas }\end{array}$ & $\mathrm{X}$ \\
\hline $\begin{array}{l}\text { 3.14 Existe no web site a possibilidade do cliente se cadastrar para } \\
\text { receber maiores informações sobre a empresa ou produtos? }\end{array}$ & & $\mathrm{X}$ \\
\hline 3.15 Existe controle de fluxo de clientes visitados & & $\mathrm{X}$ \\
\hline 3.16 Os clientes são receptivos aos novos procedimentos? & $\mathrm{X}$ & \\
\hline
\end{tabular}


9.6 Anexo 6: Quadro sinopse de identificação dos aspectos organizacionais da Best

\begin{tabular}{|l|l|l|}
\hline Características & Sim & Não \\
\hline 3.1 Há uma clara definição de cargos e funções & $\mathrm{X}$ & \\
\hline 3.2 Existem manuais de procedimentos escritos & & $\mathrm{X}$ \\
\hline $\begin{array}{l}\text { 3.3 A responsabilidade da função de vendas via Internet está } \\
\text { limitada ao cargo }\end{array}$ & $\mathrm{X}$ \\
\hline 3.4 A autoridade do setor de vendas é limitada & $\mathrm{X}$ & \\
\hline 3.5 A unidade de comando de vendas é centralizada & & $\mathrm{X}$ \\
\hline 3.6 Existe um padrão de atividades repetitivas & $\mathrm{X}$ & \\
\hline 3.7 Existem constantemente atividades criativas & & $\mathrm{X}$ \\
\hline 3.8 Os processos são formais e pré-determinados & $\mathrm{X}$ & \\
\hline 3.9 O estilo gerencial é participativo onde as decisões são conjuntas & & $\mathrm{X}$ \\
\hline 3.10 A comunicação é através de memorandos e formalizada & $\mathrm{X}$ \\
\hline 3.11 O cadastro de clientes e o processo de compras são integrados & $\mathrm{X}$ & \\
\hline 3.12 Vendas e estoque são integrados & $\mathrm{X}$ & \\
\hline $\begin{array}{l}\text { 3.13 Quando ocorre algum imprevisto, o sistema permite } \\
\text { flexibilidade do operador de vendas }\end{array}$ & $\mathrm{X}$ & \\
\hline $\begin{array}{l}\text { 3.14 Existe no web site a possibilidade do cliente se cadastrar para } \\
\text { receber maiores informações sobre a empresa ou produtos? }\end{array}$ & & $\mathrm{X}$ \\
\hline 3.15 Existe controle de fluxo de clientes visitados & & $\mathrm{X}$ \\
\hline 3.16 Os clientes são receptivos aos novos procedimentos? & $\mathrm{X}$ & \\
\hline
\end{tabular}

